\title{
Integration of Urban Freight Innovations: Sustainable Inner-Urban Intermodal Transportation in the Retail/Postal Industry
}

\author{
Zhangyuan $\mathrm{He}^{1,2, *(1)}$ and Hans-Dietrich Haasis ${ }^{1}$ \\ 1 Maritime Business and Logistics, University of Bremen, 28359 Bremen, Germany; haasis@uni-bremen.de \\ 2 International Graduate School for Dynamics in Logistics, University of Bremen, 28359 Bremen, Germany \\ * Correspondence: zhe@uni-bremen.de; Tel.: +49-174-8652437
}

Received: 27 February 2019; Accepted: 17 March 2019; Published: 22 March 2019

check for updates

\begin{abstract}
Urban population growth has permanently increased the commodity demands and freight flow within urban areas. The retail/postal industry is intent on finding appropriate internal approaches and a new business model to respond to the adverse impacts generated by urban freight activities. Usage of emerging transport modes is an efficient solution for these industries. Nevertheless, considerable research has paid less attention to the implementation status of distribution innovations, as well as to their suitability and application restrictions. Concurrently, a comprehensive consideration of various distribution innovations that operate together as a system is lacking. To this end, this paper adopted a literature review method and GE multifactorial analysis. Specifically, this paper reviewed the related articles that were published in the past six years (2013-2018) to define the concept of distribution innovations. In addition, we adopted the approach of GE multifactorial analysis to analyze the application status of distribution innovations from the perspective of academic research and company implementation. Following the suitability assessment and application of restriction analysis, we proposed the concept of sustainable inner-urban intermodal transport (SIUIT) for the retail/postal industry. This paper contributes to the sustainable urban freight literature by exploring possible future research directions of SIUIT.
\end{abstract}

Keywords: urban freight innovations; GE multifactorial analysis; intermodal transportation; sustainability

\section{Introduction}

Urban demographic expansion has led to persistent issues and emerging urban challenges, for instance urban sprawl and an aging urban population [1]. These issues and challenges are an exogenous trend that has radically influenced the urban freight system. The commodity demand growth and consumer behavior changes have continually increased the frequency of freight activities within urban areas, particularly in the retail and postal industries, which has been accompanied by significant e-commerce growth since the year 2000, increasing on average 10-20\% per year for online retail [2]. This increased activity implies that the high frequency of parcel delivery will exacerbate emission and urban congestion, as it is the primary model of transporting goods to consumers for e-commerce. For the retail industry, urban population expansion has increased the commodity demands and freight flows within urban areas. It is estimated that urban freight accounts for $10-15 \%$ of vehicle equivalent miles on a city street [3]. In addition, freight and the city maintain a set of core relations, as the city is an entity where production, distribution, and consumption movements are used and compete for scarce land [2]. To this end, the retail/postal enterprises have increasingly become concerned with balancing the relation between economic benefits and the urban environment. 
Despite the fact that urban freight movements have continually contributed to the economic growth of cities, this has caused more environmental externalities within urban areas. These externalities primary consist of air pollution, congestion, noise, etc. [4,5]. While cities are responsible for more than $70 \%$ of global carbon dioxide emissions [1], almost $5.5 \%$ of the total annual greenhouse gas emissions are generated by the logistics and transport sectors, around $57 \%$ of which are caused by road freight transport [6]. In addition, congestion is also a major issue created by urban freight. Urban freight transport (UFT) is responsible for 10-15\% of vehicles equivalent miles traveled on urban streets [3]. Of these vehicles, only $42.6 \%$ of the miles traveled were full load, and approximately $25 \%$ were entirely or half empty loaded [7]. Nevertheless, simultaneously solving these issues is difficult in the current circumstance. Hence, from the views of local authorities and urban inhabits, these externalities have fundamentally required the retail and postal industries to choose more suitable transport modes and operational strategies for the various segments of urban freight transport. Additionally, for companies that are involved in the retail/postal industry, the commodity demand growth and consumer behavior changes have resulted in companies attempting to find appropriate internal approaches and new business models to accommodate these challenges created by exogenous trends. To this end, several enterprises involved in retail/postal have used emerging transport modes while developing an innovative urban freight concept to cope with these environmental externalities in cities. For instance, Yamato Transport Co., Ltd. (Tokyo, Japan) has utilized the tram to transport parcels in the city of Sapporo since 2012 (Figure 1a) [8], and the result has presented that this system has reduced $\mathrm{CO}_{2}$ emissions and almost halved the number of trucks used for delivering parcels within urban areas [9]. In 2007, the initiative "Vracht Door De Gracht" (freight through the canal) in Amsterdam was launched by Mokum Mariteam, where the inland waterway was used to transport retail goods to consumers (Figure 1b); it is equipped with a low-noise electrical engine that generates a reduction of energy usage, as well as PM10 and $\mathrm{CO}_{2}$ emissions [10]. The results have demonstrated that these distribution innovations have enabled the effective mitigation of congestion and emission issues created by the conventional urban freight model. It is noted that, accompanied by both digital transformation and the development of information communications technologies (ICT), a majority of technology companies have developed new distribution innovations for the urban freight system. For example, Starship Co., Ltd. (Liverpool, U.K.) has developed the delivery robot (Figure 1c) for last-mile delivery, which is capable of carrying goods no more than 100 pounds [11]. Mercedes-Benz Co., Ltd. (Stuttgart, Germany) has launched Vision Vans (Figure 1d) to deliver goods on the urban freight network, which will be equipped with two delivery drones [12]. Therefore, applying distribution innovations is an efficient solution for the retail/postal companies in the future city while enabling the provision of individual logistics services, thereby increasing the enterprises' competitiveness.

However, much less research has paid attention to the application status of distribution innovations and their suitability assessment. In addition, comprehensive consideration of operation strategies and risk evaluations, particularly on various distribution innovations that operate together as a system, is lacking. Concurrently, the distribution innovations research of academia and the development projects of companies have appeared as a highly asymmetric trend. To this end, this paper adopted the literature review approach and the method of GE multifactorial analysis to respond to these issues. First, Section 3 reviews articles published in the past six years (2013-2018) using the Scopus database. We define the distribution innovations that consist of 11 emerging transport modes from the view of the retail/postal logistics system. In Section 4, GE multifactorial analysis is used to analyze the status of these distribution innovations from the two perspectives of academia and companies. Section 5 demonstrates the suitability assessment of these innovations and proposes the concept of sustainable inner-urban intermodal transport (SIUIT). 


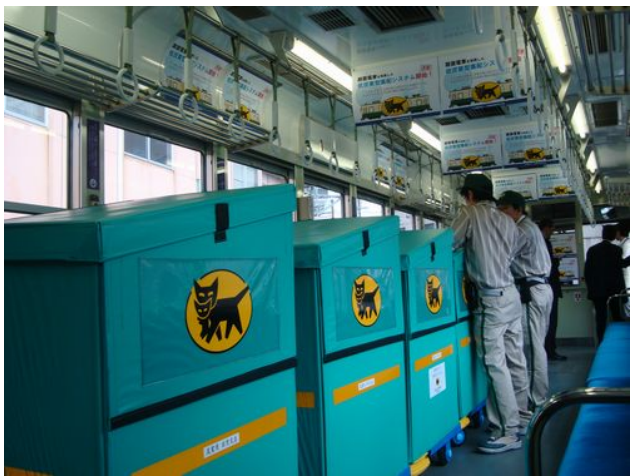

(a)

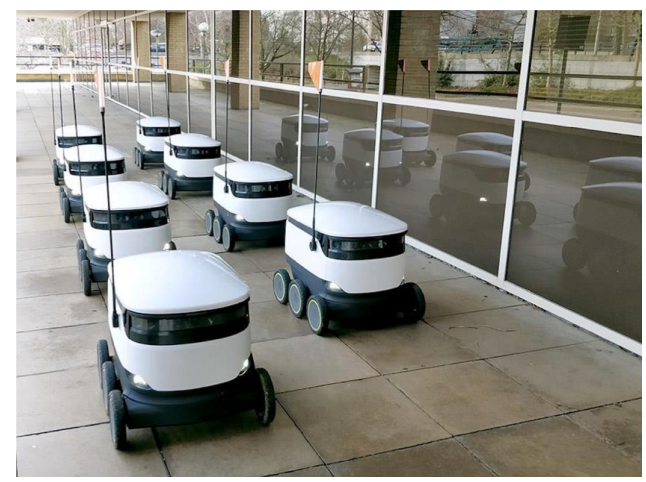

(c)

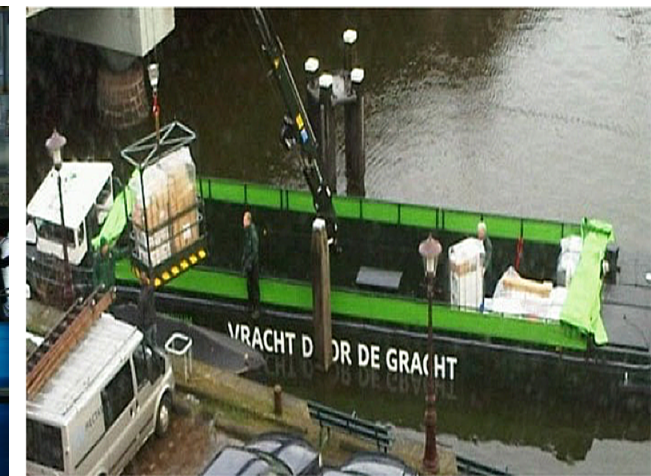

(b)

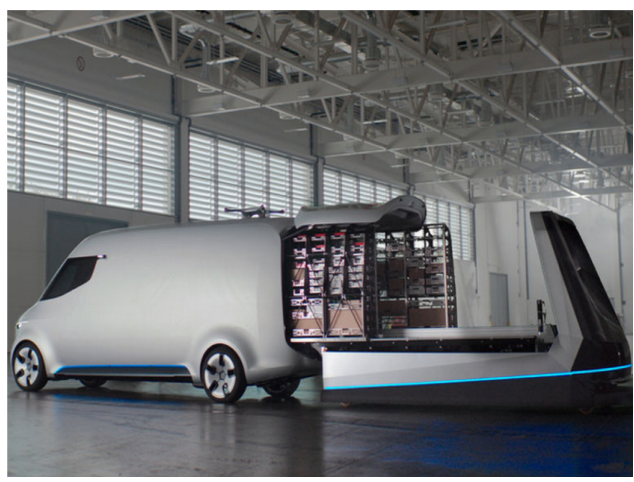

(d)

Figure 1. Several new transport modes for urban freight transport. (a) Yamato Cargo Tram (Source: [13]); (b) Vracht Door de Gracht (Source: [10]); (c) Starship Robot (Source: [14]); (d) Vision Vans (Source: [15]).

\section{Research Question and Methodology}

A considerable body of research has paid little attention to the application and research status of distribution innovations, as well as to the comprehensive consideration of their restrictions and suitability. This paper intends to analyze their application and research status and to assess their restrictions and suitability in urban freight transport. As previously mentioned, the concept of distribution innovations does not have an accurate definition, so the first research question (RQ.1) addressed in this paper is as follows:

RQ.1: In recent years, what are the emerging transport modes for distribution innovations in urban freight transport?

The related companies aim to utilize the emerging transport modes to balance the relations between economic benefits and environmental externalities by freight activities. For academic research, scholars are more concerned with the planning scheme design, impacts/risks evaluation, and policy discussions. Nevertheless, the research and application status of distribution innovations in urban freight transport reveals an asymmetry. This asymmetry is capable of restricting the application and promotion of these innovations in the urban freight system. Consequently, the principal second research question (RQ.2) is the following:

RQ.2: What is the status of the applications and research of these innovations in urban freight transport?

As mentioned previously, a lack of a comprehensive consideration of restrictions and suitability regarding the emerging transport modes exists. Given that these transport modes need to be integrated with the conventional/new modes, assessing the restrictions and suitability of them is necessary. To this end, the last research question (RQ.3) is as follows: 
RQ.3: What are the restrictions and suitability of these innovations in urban freight transport?

To respond to the above research questions, this paper opted for the approach of systematic literature reviews (SLR) and the method of GE multifactorial analysis. The research methodology is presented in Figure 2). First, we systematically reviewed the related articles published in the past six years in the Scopus database. According to the literature review, we defined the concept of distribution innovations in urban freight transport, thereby answering RQ.1. Furthermore, GE multifactorial analysis was used to formulate the GE matrix from the views of academic research and company applications. Then, we utilized the GE matrix to analyze the status of these distribution innovations. Finally, this paper assessed the restrictions and suitability of these innovations through the previous SLR, as well as the related reports from companies. Concurrently, we proposed the concept of sustainable inner-urban intermodal transport to integrate these distribution innovations into one system.

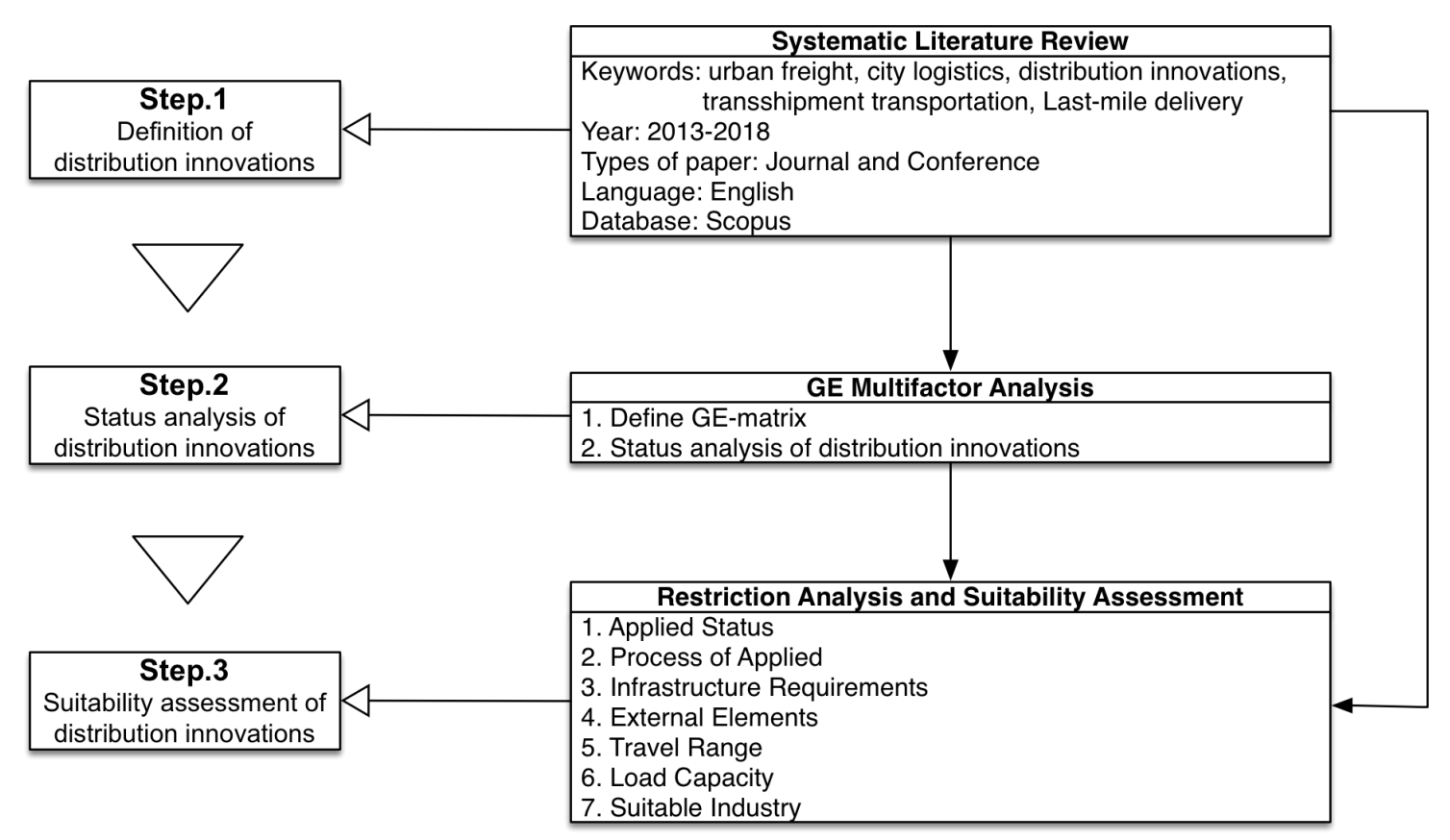

Figure 2. Research methodology.

\section{Literature Review of Distribution Innovations}

In recent decades, numerous emerging technologies have been widely implemented in the urban freight system. Urban distribution innovations refer to the transportation enterprises that apply the emerging urban transport mobility to the transship/delivery of goods within urban areas and are intended to reduce the negative impacts created by freight movements and provide the diversification of logistics services. For instance, electric vehicles and cargo bikes are such innovations. However, the lack of a comprehensive analysis regarding the various distribution innovations and their application range remains. To this end, this paper adopted the literature review approach to understand the distribution innovations and analyze the research and implementation status of these emerging technologies. Table 1 demonstrates the indicators of the paper selection.

According to the indicators of the paper selection, the titles and abstracts of the selected papers were reviewed for each paper. After a discussion and analysis, papers that were unrelated to the research topic were removed from the bibliography corpus. Moreover, almost 70 papers were not strictly concerned with emerging transport modes in transshipment transportation or last-mile delivery. 
Table 1. Paper selection.

\begin{tabular}{cc}
\hline Items & Description \\
\hline Main keywords & Urban Freight Transport, City Logistics, Transshipment transportation, Last-mile delivery \\
Inclusion criteria & Transportation, Economic, Management \\
Language & English \\
Document types & Journal Articles and Conference Papers \\
Source & Scopus \\
Time interval & $2013-2018$ \\
\hline
\end{tabular}

These papers have instead focused on particular issues, for instance health, social perspectives, and urban planning. Furthermore, some papers that utilized methods with different logistics or management, such as chemical or environmental approaches, were excluded. Meanwhile, we removed the articles that were not related to the previous definition of urban distribution innovations. For example, some papers focused on the goods consolidation between various companies out of the urban consolidation center (e.g., [16-18]); many articles studied the application of internet communication technology to design new delivery strategies (e.g., [19-25]). Finally, 93 papers were analyzed and classified in the bibliography corpus that were published in the past six years (2013-2018). The main topics of these papers contained two types: transshipment transportation and last-mile delivery. The results of the topics identification are reported in Table 2.

Table 2. Topics in the paper corpus of distribution innovations.

\begin{tabular}{|c|c|c|c|}
\hline Topic & Description & $\begin{array}{l}\text { Transshipment } \\
\text { Transportation }\end{array}$ & $\begin{array}{l}\text { Last-Mile } \\
\text { Delivery }\end{array}$ \\
\hline Electric vehicles & $\begin{array}{l}\text { Applied the E-vehicles to transport the goods in } \\
\text { urban areas }\end{array}$ & [26-30] & {$[26-58]$} \\
\hline $\begin{array}{l}\text { Modular } \\
\text { E-vehicles }\end{array}$ & $\begin{array}{l}\text { The special type of vehicles is used to deliver the goods } \\
\text { to consumers by carrying one or multiple } \\
\text { cabin modules }\end{array}$ & & [59-61] \\
\hline $\begin{array}{l}\text { Public transit } \\
\text { system }\end{array}$ & $\begin{array}{l}\text { Integrated the passenger and freight activities } \\
\text { (i.e., tram, subway, bus) }\end{array}$ & [62-75] & [76] \\
\hline $\begin{array}{l}\text { Urban waterway } \\
\text { logistics }\end{array}$ & $\begin{array}{l}\text { Utilized a ship to transfer goods to the transit points by } \\
\text { the inland waterway of the city }\end{array}$ & [77-79] & {$[10,79]$} \\
\hline Taxi logistics & $\begin{array}{l}\text { Applied the taxi to transport goods; the purpose is } \\
\text { reduce traffic congestion }\end{array}$ & & [80-84] \\
\hline Cargo bike & $\begin{array}{l}\begin{array}{l}\text { Use of a cargo-bike for freight distribution in city } \\
\text { centers }\end{array} \\
\text {. }\end{array}$ & & [85-98] \\
\hline Robotic vehicles & $\begin{array}{l}\text { Use of autonomous (robotic) vehicles for freight } \\
\text { distribution in city areas }\end{array}$ & & [99-107] \\
\hline Delivery drones & Use of drones for freight delivery in city areas & & [108-111] \\
\hline Parcel lockers & $\begin{array}{l}\text { The implementation of parcel lockers aims to reduce } \\
\text { the traffic congestion in residential areas and enhance } \\
\text { the efficiency of delivery }\end{array}$ & & [112-114] \\
\hline Mobile depot & $\begin{array}{l}\text { A mobile depot is a trailer fitted with a loading dock, } \\
\text { warehousing facilities, and an office }\end{array}$ & & [115-117] \\
\hline
\end{tabular}

Figure 3 demonstrates the distribution by year of the papers in the corpus. The number of papers regarding distribution innovations reveals a spurt in growth trends, particularly in the year 2016. Concurrently, the peak of conference papers also occurred in this year, almost 14 papers. In contrast, the peak of the journal articles related to distribution innovations occurred in 2018 since some journals have called for papers regarding their Special Issues in the year 2018, for instance Transportation Science. 


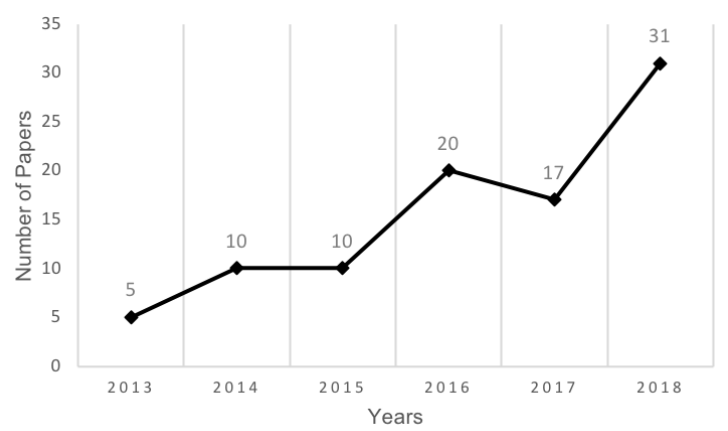

(a)

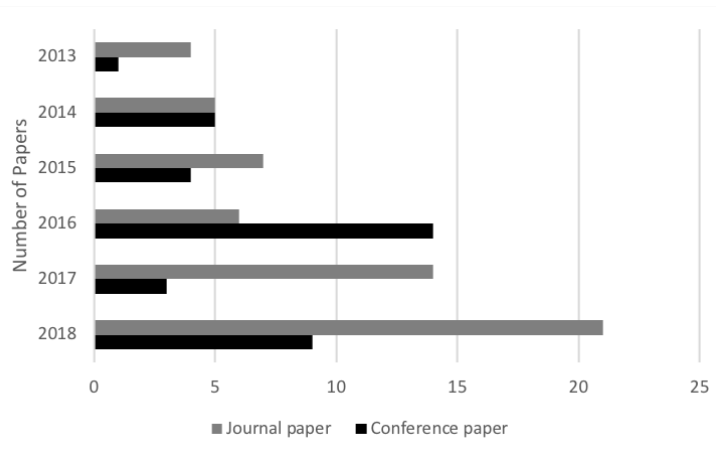

(b)

Figure 3. Description of bibliography corpus: (a) is the number of papers by year, and (b) is the number of papers by classification.

As mentioned previously, the bibliography corpus involves 93 papers in terms of the distribution innovations in the urban freight system. Commonly, the investigation of distribution innovations has focused on the process of transshipment transportation or last-mile delivery. According to a systematical literature review, some research has considered both of these processes. For instance, the papers regarding electric vehicles have simultaneously discussed the application and promotion in both processes [26-28]. Therefore, the number of papers on transshipment transportation and last-mile delivery was 22 and 77, respectively. Although the Scopus database lacks the literature of the delivery robot, this paper also considering this emerging transport mode. Table 3 shows that 11 topics have discussed distribution innovations.

The results illustrated that the topics regarding electric vehicles and cargo bikes have received more attention in the last six years since these innovations are able to mitigate congestion and environmental externalities created by freight activities within urban areas. This notwithstanding, these two topics have been given more attention regarding last-mile delivery (47 papers), and only five articles were related to transshipment transportation. It is noted that some papers on last-mile delivery have mentioned transshipment transportation or urban freight network structure design, but these are not the main research question in these papers, for instance [115].

Therefore, according to the literature review of the past six years, we have defined the scope of distribution innovations (as presented in Table 3). There are eleven emerging transport modes/concepts that are included in it. However, little research has focused on the implementation status of these distribution innovations and their application restrictions in urban areas. To this end, this paper adopted the GE multifactorial analysis approach to discuss these questions from the perspective of academia and companies.

Table 3. Research range and methodology.

\begin{tabular}{cc}
\hline Items & Description \\
\hline Research objectives & $\begin{array}{c}\text { Electric vehicles, modular E-vehicles, cargo bikes, delivery drones, public } \\
\text { transit system, robotic vehicles, taxi logistics, urban waterway logistics, } \\
\text { parcel lockers, mobile depots, delivery robot }\end{array}$ \\
\hline Research method & GE multifactorial analysis \\
\hline Research perspectives & Academic research, company application \\
\hline
\end{tabular}

\section{Implementation Status Analysis of Distribution Innovations}

\subsection{Definition of Implementation Status}

GE multifactorial analysis was first developed by McKinsey for General Electric in the 1970s. It is a method used in brand marketing and product management to assist a company in deciding what 
product(s) to add to its product portfolio and which opportunities in the market that they should continue to invest in [118]. In general, there are two dimensions used to evaluate the existing portfolios of strategic business units. Each dimension is classified into three levels to create the two-dimensional matrix. The GE matrix is able to assist a strategic business unit to evaluate its overall strength, as each product, service, and brand is mapped in this two-dimensional matrix. The advantage of this method is an intuitive analysis of relevant elements, as well as the strength evaluation. Consequently, this paper adopted this method to analyze the implementation status of distribution innovations.

First, this paper defined the two dimensions of the academia research phase and company implementation phase. Following a review of the related articles, we classified each dimension into three phases (as presented in Table 4).

Table 4. Research and implementation phase of two perspectives.

\begin{tabular}{cccc}
\hline & Low Phase & Medium Phase & High Phase \\
\hline $\begin{array}{c}\text { Academia } \\
\text { research phase }\end{array}$ & $\begin{array}{c}\text { Conceptual } \\
\text { Model phase }\end{array}$ & $\begin{array}{c}\text { Analysis and planning } \\
\text { phase }\end{array}$ & $\begin{array}{c}\text { Promotion and } \\
\text { evaluation phase }\end{array}$ \\
\hline $\begin{array}{c}\text { Companies } \\
\text { research phase }\end{array}$ & $\begin{array}{c}\text { Theoretical } \\
\text { research phase }\end{array}$ & $\begin{array}{c}\text { Testing and } \\
\text { development phase }\end{array}$ & $\begin{array}{c}\text { Operation and } \\
\text { improvement phase }\end{array}$ \\
\hline
\end{tabular}

According to the systematic literature review, the distribution innovations research in academia is capable of being classified into three phases: (1) conceptual model phase, (2) analysis and planning phase, and (3) promotion and evaluation phase. The definitions are as follows:

- The conceptual model phase refers to scholars proposing and designing the conceptual model/framework to respond to social economic questions. This is the initial stage for studying the innovative technology. Examples include the use of the delivery drone in last-mile delivery $[108,109]$ and the application of autonomous vehicles in urban freight transport [101-104].

- The analysis and planning phase is based on the specific parameters of the technology, thereby analyzing the future risks, costs, and the possible impacts of the technology application while planning both the operational scheme and the ex ante evaluation. An example is the integrated system of passenger and freight transport [80,82].

- The promotion and evaluation phase refers to scholarly discussions regarding alternative strategies that aim to promote the use of innovative technologies in urban freight transport and the evaluation of costs, as well as impacts to improve the policy or strategy. Commonly, this approach is based on private enterprises, and local authorities have already used these technologies. An example is the research regarding electric vehicles $[28,33,34,38]$ and cargo bikes $[85,90]$.

From a transition perspective, history has shown that established technologies are often slowly replaced with emerging technologies $[115,119]$. Hence, the application of emerging technologies should consist of these three phases.

According to the review of the research reports (e.g., [120]), the case studies in the articles (e.g., [121]), and the official websites of enterprises (e.g., [12,122]), we have defined the application phases from the perspective of the company. This approach also enabled a classification into three phases: (1) theoretical research phase, (2) testing and development phase, and (3) operation and improvement phase. The specific definitions are as follows:

- The theoretical research phase is the initial phase for the companies, which proposes the technology's theoretical model and conceptual model. The purpose is to identify the application range and features of technologies. For example, in 2018, Germany's Volkswagen proposed a project that integrates autonomous vehicles into the mobile depots.

- The testing and development phase is based on the result of the theoretical research phase and aims to develop the technology physical model. Concurrently, the performance is tested, and the 
possible risks are evaluated. An example is the use of drones to deliver goods within urban areas (e.g., [123]).

- The operation and improvement phase describes how the companies have used the established technologies to provide the logistics service while improving these technologies and thereby reducing the costs and risks. An example is the utilization of cargo bikes in last-mile delivery (e.g., [86]).

Therefore, the company application phase of technology consists of three phases. In addition, these three phases correspond to the academic research phases on the technology application. Based on these, we established the GE matrix of the implementation status analysis (as demonstrated in Figure 4).

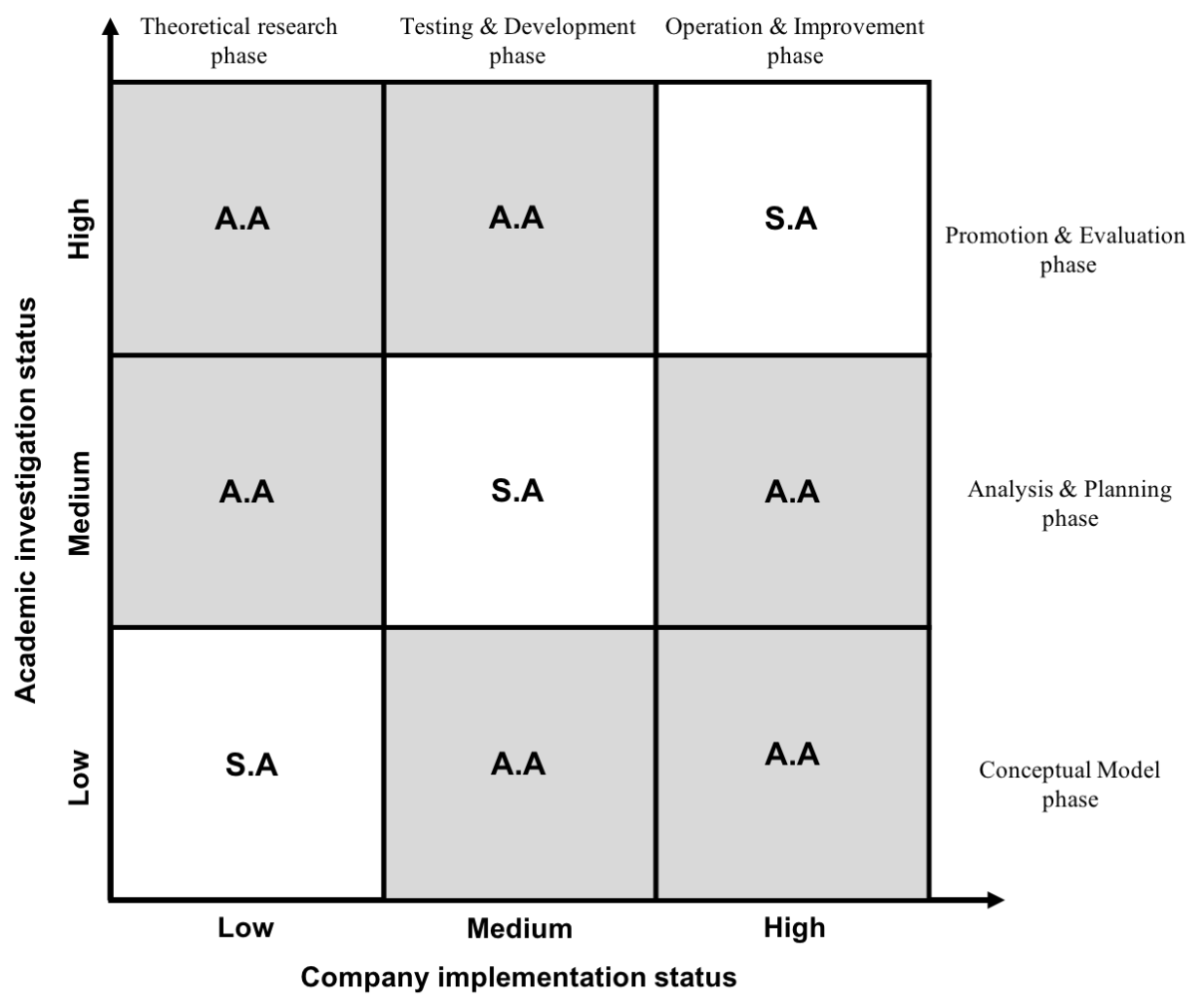

S.A: Symmetric Area

A.A: Asymmetric Area

Figure 4. The GE matrix of the implementation status analysis.

\subsection{Analysis of Implementation Status}

As mentioned by the German logistics company BVL International in its publication "Trends and Strategies in Logistics and Supply Chain Management-Digital Transformation Opportunities" in 2017, they adopted the questionnaire approach to understanding the status of applying technologies in the logistics industry. In this report, the questionnaire was used in conducting interviews with 38 experts in manufacturing, logistic services, trade, and consultancy. In addition, "the result was taken further quantitatively in an online survey with 1351 participants, of which 363 completed data sets assured a statistically reliable and detailed analysis" [120].

Figure 5 demonstrates the relevance and implementation status of technologies and defines the innovative technology concepts in logistics. The autonomous vehicles, drones, robots, and driverless transport systems are at a very low level regarding the aspect of implementation status. It is noted that this report has presented that $73 \%$ of companies have approved the emerging technologies, giving rise to the development of substantial opportunities [120]. The notwithstanding, more than $50 \%$ of 
the enterprises indicated a "wait-and-see" attitude until tried and tested solutions are available for practical application [120]. Consequently, logistic enterprises currently lack an efficient integration solution to the implementation of innovative technologies, while considerable research has paid little attention to the relevance among the different technologies.

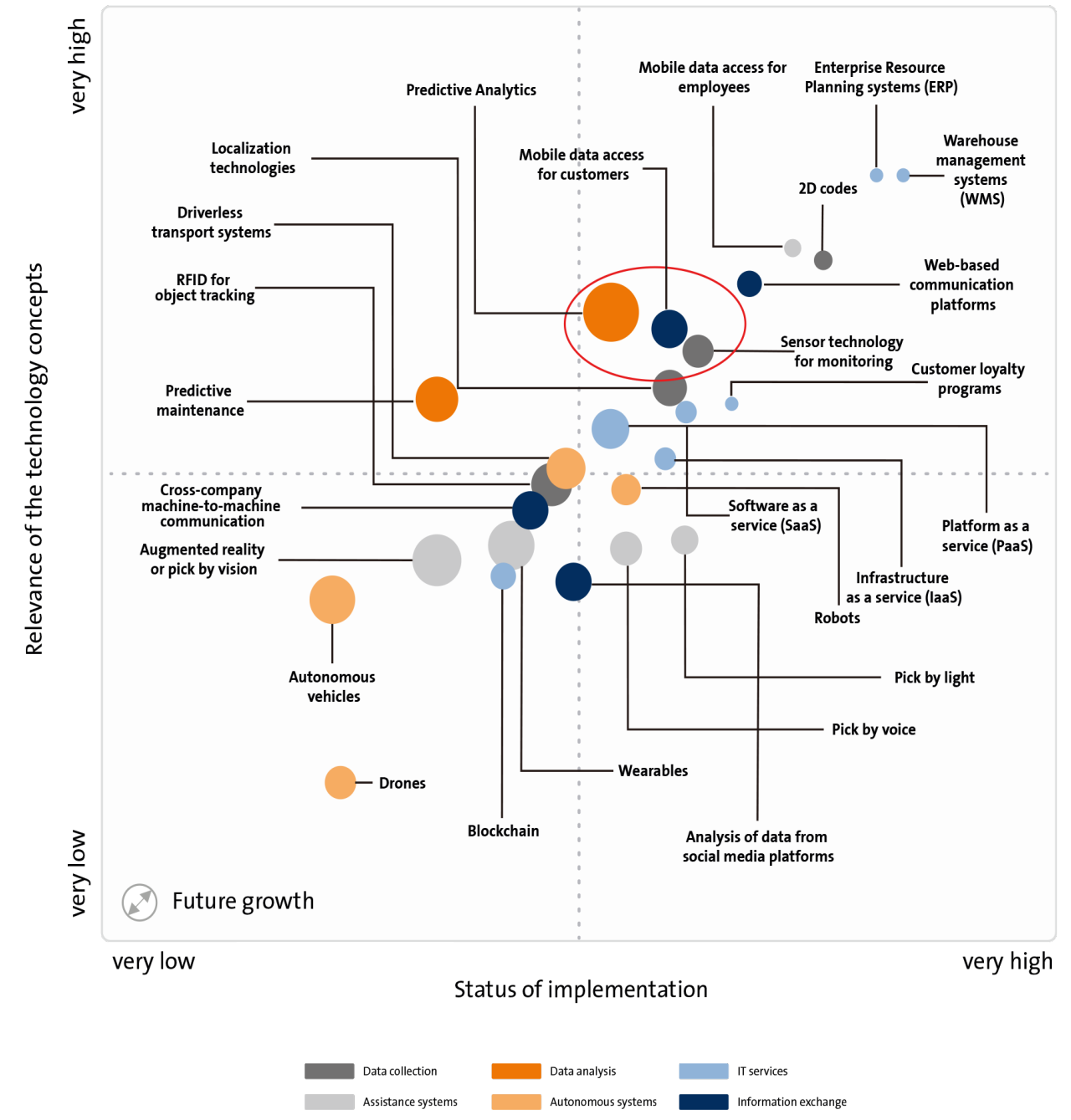

Figure 5. The relevance and implementation status of the studied technology concepts (source: [120]).

According to the literature review, applying the autonomous vehicles in urban freight transport is currently in the theoretical research stage. There were nine articles related to autonomous vehicles (AVs) in urban freight transport. Mitrea and Kyamakya [101] have discussed the assessment and prediction of the impact of various autonomous driving use cases on urban freight transport. Vleugel and Bal [99] have indicated that the AVs are able to reduce the use of space (50\%) in cities and emissions by this transport. Yu and Lam [102] have proposed the AV logistic system (AVLS) and used a quadratic-constrained mixed integer linear program to formulate the joint routing and charging problem. The result indicated that AVLS can effectively utilize excessive renewable energy and satisfy all logistics demands. Haas and Friedrich [100] have developed a microsimulation tool for AVs used in city logistics from the perspective of the travel time. Molfino et al. [103] and Dinale et al. [104] have designed a conceptual architecture of a robotic vehicle that integrates a robotic handling device that is positioned in the vehicle. These papers imply that the research regarding autonomous vehicles is in the conceptual model stage. In regards to companies, Mercedes-Benz is developing Vision Vans as autonomous vehicles to deliver goods in the urban freight network [12]. The British company Ocado has trialed driverless vans to transport commodities in London, which will be in operation in 
all of Britain by 2019 [124]. This progress illustrates that the relevant companies are in the testing and development stage.

Delivery drones are commonly used in the last-mile delivery in urban freight transport. According to the literature review, the studies related to delivery drones are also in the conceptual model stage. For instance, Kunze [108] has proposed the concept of "Post 4.0", which integrates ground drones and small unmanned aircraft systems (sUAS) in the future urban freight system. In addition, some scholars are involved with cooperation among delivery drones and other innovative technologies. For example, Mckinnon [109] have discussed and analyzed the possible impacts of 3D-printing and drones on last-mile delivery. Additionally, the relevant enterprises are actively developing and improving the performance of delivery drones used in the last-mile delivery that are equipped with a delivery drone in various vehicles. Amazon is developing a UAV delivery system called Amazon Prime Air, which is a cargo airline and conceptual drone-based delivery system, and goods can be delivered to customers just in $30 \mathrm{~min}$ [123]. The Workhorse Group has developed the HorseFly UAV Delivery system, which is fully integrated with electric/hybrid delivery trucks, while UPS has tested residential delivery with a drone launched from Atop Package Car [122]. Mercedes-Benz is developing Vision Vans that will be equipped with two delivery drones [12]. It is noteworthy that several logistic companies have utilized drones to deliver special goods to consumers. For instance, in 2013, DHL Parcel launched a research project on the use of a particular drone, dubbed the "Parcelcopter", for transporting goods under real conditions to remote or geographically-challenging areas [125]. However, thus far, the use of delivery drones in urban freight transport is still in the development and testing phase for relevant companies.

The delivery robot is an emerging freight technology that enables reducing traffic congestion and saves labor costs. In the Scopus database, there is a lack of research regarding the use of the delivery robot in urban freight. Nevertheless, this innovative technology has received more attention in logistic corporations. For instance, the Starship firm has developed delivery robots to carry cargoes within the urban environment, and the capacity of cargo-carrying is no more than 100 pounds. [11]. The Chinese retail companies JingDong, CaiNiao, etc., are also developing delivery robot networks and testing their performance. Hence, for the relevant companies, the delivery robot remains in the development and testing phase.

The advantages of electric vehicles (EVs) have been widely recognized by academia in recent years. Concurrently, many local authorities have also positively formulated a policy that aims to promote the application of EVs in urban freight. The reason is that much research on EVs is related to replacement strategies $[28,38,42,50]$ and cost evaluation $[33,34,36,45]$, as well as the choice of vehicle routing. Hence, the use of EVs in urban freight is in the operation and improvement phase.

The implementation status of cargo bikes is comparable to that of EVs. As mentioned in Section 2, there are 14 articles regarding the use of cargo bikes in the last-mile delivery. These studies have focused on operational strategies and impact analyses, as well as cost evaluation. In real-world settings, many logistics companies have applied cargo bikes to urban freight transport, such as DHL Germany. Moreover, some manufacturers have developed an innovative cargo bike to enhance the load capacity and delivery range within urban areas. For instance, the Velove Armadillo cargo bike produced by the Swedish company Velove [126]. Consequently, the implementation status of cargo bikes is in the operation and improvement phase.

Modular vehicles (MVs) are a particular type of vehicle that is used to deliver goods to consumers by carrying one or multiple cabin modules. In the papers corpus, there were three articles regarding this topic. Indeed, the modular vehicle is a special EV [59-61]. Notwithstanding, these articles are in the conceptual model phase. From the view of case studies in these papers, the logistic service companies and manufacturers are in the theoretical research phase.

The integrated system of passengers and freight transport consists of trams, metros, buses, and taxis. The relevant articles that have presented investigations of this topic are in the analysis and planning phase. For instance, Kelly and Marinov [62] proposed a conceptual system of urban freight transport that integrated the light rail system. Chen and Pan [80], as well as Li et al. [82] discussed 
the feasibility of people and parcels sharing taxis. Indeed, the relevant enterprises and manufacturers have developed and tested the integrated system of passengers and freight transport. For example, the Yamato Transport Company has been utilizing a tram system for distributing goods to Arashiyama in Kyoto, Japan, since May 2011 [13]. However, thus far, many companies have not yet adopted this system to transport goods within urban areas due to financial reasons, possible risks, etc. Hence, from the perspective of the company, the integrated system of passengers and freight transport is in the testing and development phase.

Urban waterway logistics (Inland waterway) refer to using ships to transfer goods to the transit points by the inland waterway of a city. According to the literature review, the studies of the inland waterway in urban freight transport are in the analysis and planning phase. Due to the implementation condition that the city needs to have an inland waterway, the broad application of this system in the logistics service company is restricted. Hence, for the company, inland waterway transport is in the testing and development phase.

The parcel locker is commonly used in the parcel or B2C industry. According to the literature review, much research is analyzing and evaluating the application of parcel lockers [112,113]. Indeed, a multitude of logistics service companies have used the parcel locker in urban freight transport, such as Amazon Co. and DHL Co.

A mobile depot is a trailer fitted with a loading dock, warehousing facilities, and an office. In the Scopus database, only four articles were related to this topic. The literature review indicates that these research studies consist of a conceptual model design [121], cost analysis, and evaluation $[115,116,127]$. In these papers, TNT Express in Brussels has used this system in urban freight transport $[116,121]$. Hence, thus far, the mobile depot is in the testing and development phase from the perspective of companies.

Based on the previous analysis, Figure 6 demonstrates the implementation status of distribution innovations based on the GE two-dimensional matrix. Currently, modular E-vehicles are still at the low-low phase. Electric vehicles and parcel lockers have been at the high-high level of application, and academia and companies have paid more attention to them as replacement policies and promotion strategies within urban areas. In contrast, delivery drones, delivery robots, mobile depots, and robotic vehicles have so far still maintained a medium-low level of application. The costs and external elements (e.g., weather, vandalism) have radically restricted their wide application in enterprises. Moreover, the taxi delivery is at the low-medium level, where immature technology and local transport policies are the primary barriers for applying these in urban freight transport. It is noted that public transit systems and inland waterway transportation are at the level of medium-medium. This observation implies that the integrated freight and passenger model in urban freight transport has increasingly become the future operational measure in city logistics. This notwithstanding, the enterprises still need to promote the implementation phase of these emerging technologies to the next level actively, while academic research has to consider comprehensively the relevant elements to evaluate risks and make the operational measures and policies for local authorities and private companies. In addition, applying the cargo bike to the delivery of goods has received more attention in recent years. A majority of tech companies have developed innovative cargo bikes equipped with a large container and mechanical transmission devices to enhance the delivery range, for instance the cargo bike of Velove Armadillo developed by Velove Corporation [126], which was utilized by DHL in German cities in 2018. However, academic research is still in the analysis and planning phase. The future research direction of the innovative cargo bike is in the promotion and evaluation phase. In summary, the various distribution innovations are in different implementation phases. These innovative units have formed the new urban intermodal transportation concept, which is a necessary consideration in the future agenda of urban freight planning. 


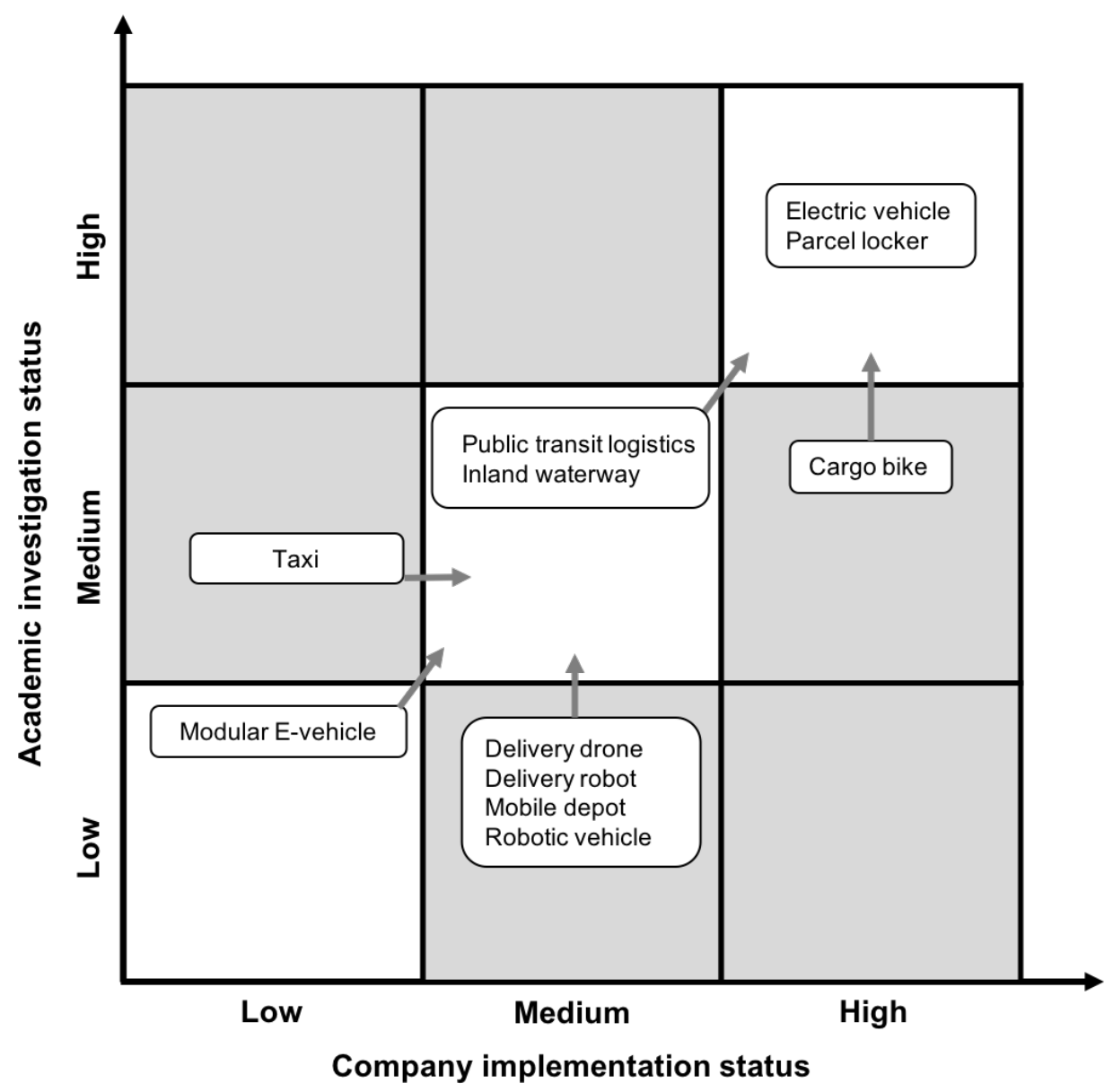

Figure 6. The technology implementation status in urban freight transport.

Nevertheless, there is a lack of a comprehensive consideration regarding the integration of all emerging technologies. A considerable body of research has paid scant attention to feasibility analyses and risk evaluations of urban intermodal transport with these emerging technologies. Hence, future research is needed to consider the interrelation and interplay among the various innovative technologies on urban freight transport. Additionally, it is necessary to consider the network structure of urban freight transport. From a view of urban freight network design, the application of emerging technologies and freight network structure are the primary influence factors that need to be analyzed. Understanding the implementation status regarding these technologies contributes to future network design on urban freight transport.

\section{Application Restriction and Scope of Distribution Innovations}

\subsection{Applied Restriction of Distribution Innovations}

As mentioned previously, much research lacks a comprehensive consideration of the combined applications of the emerging transport modes as a system. The research of various distribution innovations is highly fragmented. The primary barrier that exist for the application restrictions of these innovations concerns the operational processes within urban areas. For instance, such processes include weather, urban freight policy, urban topography, and technical limitations. Hence, this paper has assessed the restriction of these 11 emerging transport modes from seven aspects:

- Status: This is based on the previous GE-matrix analysis. According to the analysis of the implementation status of the distribution innovations, some of them are in the low-low phase. 
This status poses challenges in finding the technical data of these transport modes because they are in the development phase for the related companies, for instance modular E-vehicles.

- Process of application: As mentioned previously, the processes of city logistics consist of transshipment transportation and last-mile delivery. The capacity and size of distribution innovations have restricted their application process in urban freight transport. For instance, the delivery drone is generally only utilized in the last-mile delivery.

- Infrastructure requirements: The infrastructure requirements of various innovations are different. For example, the use of electric vehicles should consider the location of the charge station and the application of delivery drones should not only consider this critical point, but also consider the control platform and loading dock.

- External elements: In addition to the technical limitation itself, external elements have influenced the application of these distribution innovations on urban freight transport. Weather is a critical impact factor for the application of distribution innovations. Storms, wind, and snow are unfavorable to the use of these innovations (delivery drone, delivery robot, etc.). In addition, the external elements are associated with urban freight policies, related laws, urban topography, and so on.

- Travel range: This is a crucial indicator for assessing the suitability of transport modes. Concurrently, this indicator contributes to the selection of transport modes for the companies, particularly to address distinct delivery demands and complex urban topography.

- Load capacity: This is a pivotal criterion to measure a suitable industry for transport modes. The distribution innovations with a small capacity generally have been used in parcel delivery, such as the delivery drone/robot. However, the load capacity of some distribution innovations appears to be flexible and uncertain. For instance, public transit logistics are based on the spare capacity of the tram/bus/subway $[128,129]$. The load capacity of taxi logistics depends on the taxi types, which in general is approximately $0.5-2 \mathrm{~m}^{3}[130,131]$.

- Suitable industry: As the research perspectives of this paper are related to the retail and postal industries, we have analyzed the suitable industries of these emerging transport modes from these two aspects. Generally, the load capacity and travel range are critical factors for measuring their suitable industries. It is noted that the transshipment transportation process of the parcel industry also requires vehicles with a large load capacity. Consequently, flexibility and sustainability are also the key points for analyzing suitable industries.

Table 5 demonstrates the suitability assessment of distribution innovations. The technical data regarding the travel range and load capacity of modular e-vehicles and robotic vehicles are difficult to find. The problem is that both of these innovations are still in the exploitation phase for technology companies. In addition, taxi logistics are still in the testing and planning phases, and the load capacity data are based on the taxi types from the official report of Mercedes-Benz. 
Table 5. Suitability assessment of distribution innovations.

\begin{tabular}{|c|c|c|c|c|c|c|c|}
\hline & Status & $\begin{array}{l}\text { Process of } \\
\text { Application }\end{array}$ & Infrastructure Requirements & External Elements & Travel Range & Load Capacity & $\begin{array}{l}\text { Suitable } \\
\text { Industry }\end{array}$ \\
\hline $\begin{array}{c}\text { Electric } \\
\text { vehicles }\end{array}$ & High-high phase & $\begin{array}{l}\text { Transshipment } \\
\text { transportation/ } \\
\text { last-mile delivery }\end{array}$ & Charge station & Urban topography & $\begin{array}{c}100-500 \mathrm{~km} \\
{[39,45]}\end{array}$ & $3-20 \mathrm{~m}^{3}[39,45]$ & Retail/Post \\
\hline $\begin{array}{l}\text { Modular } \\
\text { E-vehicles }\end{array}$ & Low-low phase & $\begin{array}{l}\text { Transshipment } \\
\text { transportation/ } \\
\text { last-mile delivery }\end{array}$ & Charge station & Urban topography & N.A. & N.A. & Retail/post \\
\hline $\begin{array}{l}\text { Public } \\
\text { transit } \\
\text { logistics }\end{array}$ & $\begin{array}{l}\text { Medium-medium } \\
\text { phase }\end{array}$ & $\begin{array}{l}\text { Transshipment } \\
\text { transportation }\end{array}$ & $\begin{array}{l}\text { Integrated station of transit } \\
\text { and freight }\end{array}$ & $\begin{array}{l}\text { Off-peak periods of } \\
\text { passenger }\end{array}$ & $\begin{array}{l}\text { Based on the } \\
\text { range of the } \\
\text { public transport } \\
\text { network }\end{array}$ & $\begin{array}{c}\text { Standardized box is approximately } \\
1.5-2 \mathrm{~m}^{3}[62] \text {, and the number of } \\
\text { boxes is based on the spare capacity } \\
\text { of public transit modes } \\
\text { (approximately } 15 \text { boxes) }[128,129]\end{array}$ & Retail/post \\
\hline $\begin{array}{l}\text { Urban } \\
\text { waterway } \\
\text { logistics }\end{array}$ & $\begin{array}{l}\text { Medium-medium } \\
\text { phase }\end{array}$ & $\begin{array}{l}\text { Transshipment } \\
\text { transportation }\end{array}$ & $\begin{array}{l}\text { Multiple canal loading docks or ship } \\
\text { equipped with a hydraulic crane that } \\
\text { delivers the goods to the quays }\end{array}$ & $\begin{array}{l}\text { City's extensive canal } \\
\text { network, weather }\end{array}$ & $\begin{array}{l}\text { Based on urban } \\
\text { canal network }\end{array}$ & $30-85 \mathrm{~m}^{3}$ [10] & Retail/post \\
\hline $\begin{array}{c}\text { Taxi } \\
\text { logistics }\end{array}$ & $\begin{array}{l}\text { Low-medium } \\
\text { phase }\end{array}$ & Last-mile delivery & No special requirements & $\begin{array}{l}\text { Urban transport policy, } \\
\text { taxi policy }\end{array}$ & 600-1000 km [130] & $\begin{array}{l}\text { Based on the taxi types, generally is } \\
\text { approximately } 0.5-2 \mathrm{~m}^{3}[130,131]\end{array}$ & Post \\
\hline $\begin{array}{c}\text { Cargo } \\
\text { bike }\end{array}$ & $\begin{array}{l}\text { High-medium } \\
\text { phase }\end{array}$ & Last-mile delivery & Charge station & $\begin{array}{l}\text { Weather, urban } \\
\text { topography }\end{array}$ & $13-100$ km [85] & Approximately $1-2 \mathrm{~m}^{3}[126]$ & Post \\
\hline $\begin{array}{l}\text { Robotic } \\
\text { vehicle }\end{array}$ & $\begin{array}{l}\text { Medium-low } \\
\text { phase }\end{array}$ & $\begin{array}{l}\text { Transshipment } \\
\text { transportation/ } \\
\text { last-mile delivery }\end{array}$ & $\begin{array}{c}\text { Charge station, controller platform, } \\
\text { urban road network }\end{array}$ & $\begin{array}{l}\text { Urban freight policy, } \\
\text { law allows }\end{array}$ & N.A. & N.A. & Retail/post \\
\hline $\begin{array}{l}\text { Delivery } \\
\text { drone }\end{array}$ & $\begin{array}{l}\text { Medium-low } \\
\text { phase }\end{array}$ & Last-mile delivery & $\begin{array}{c}\text { Charge station, controller platform, } \\
\text { loading depots/trucks }\end{array}$ & $\begin{array}{l}\text { Weather, human } \\
\text { damages, law allows }\end{array}$ & $\begin{array}{c}\text { A range of about } \\
20-30 \mathrm{~km} \\
{[111,132,133]}\end{array}$ & Approximately 2-4 kg [111,132,133] & Post \\
\hline $\begin{array}{l}\text { Delivery } \\
\text { robot }\end{array}$ & $\begin{array}{l}\text { Medium-low } \\
\text { phase }\end{array}$ & Last-mile delivery & $\begin{array}{c}\text { Charge station, controller platform, } \\
\text { loading depots/trucks }\end{array}$ & $\begin{array}{l}\text { Weather, topography, } \\
\text { law allows, human } \\
\text { damages }\end{array}$ & $\begin{array}{l}\text { Within a 3-km } \\
\text { radius [11] }\end{array}$ & No more than 50 pounds [11] & Post \\
\hline $\begin{array}{l}\text { Parcel } \\
\text { locker }\end{array}$ & High-high phase & Last-mile delivery & No special requirements & Weather & N.A. & Approximately 1.36-25.84 m³ [134] & Post \\
\hline $\begin{array}{c}\text { Mobile } \\
\text { depot }\end{array}$ & $\begin{array}{l}\text { Medium-low } \\
\text { phase }\end{array}$ & Last-mile delivery & NO special requirements & $\begin{array}{l}\text { Urban freight policy, } \\
\text { parking limitation }\end{array}$ & $\begin{array}{l}\text { Depends on the } \\
\text { type of tractor } \\
\text { and urban acreage }\end{array}$ & Fits 4 large and 7 smaller cages [135] & Retail/post \\
\hline
\end{tabular}


In summary, these 11 distribution innovations have been/will be used in city logistics. The result of the suitability assessment has indicated that the application of these innovations is a viable and efficient solution for urban freight transport in the future. Their advantages are that they mitigate the conflict between the city and freight aspects regarding land, while alleviating the negative impacts for urban environments. In addition, the use of delivery drones and delivery robots will provide increasingly more individualization of logistics services, thereby increasing enterprises' competition ability and economic scale. However, research attention is lacking on the operation of these innovations together as a system. Regardless, in the literature review of distribution innovations, we determined that some innovations have operated together. For instance, the mobile depot has operated with cargo bikes and small E-vehicles $[115,116]$. Some companies have utilized a combination of vans to transport small containers to the locations where cargo bikes are then responsible for the last-mile delivery. For example, DHL company (as depicted in Figure 7) has implemented this approach.

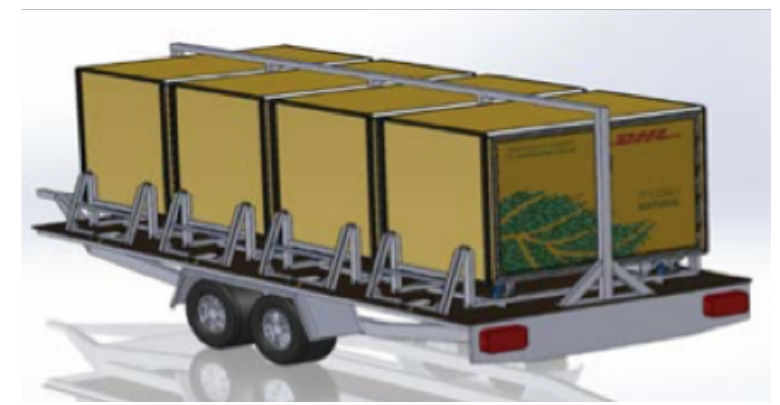

Figure 7. The combination module of vans for small containers (Source: [136]).

\subsection{Sustainable Inner-Urban Intermodal Transportation}

As mentioned previously, some companies have operated one or two distribution innovations together as a system. Following the literature review of these distribution innovations, we determined that some city logistics providers and technology enterprises have launched new concepts of integrated operation among these technologies, while they have begun to test them in the real world. For instance, Swedish company Velove has proposed the concept of the containerized urban last-mile delivery solution. This refers to parcels being placed in containers at the sorting terminal, using an electric vehicle equipped with a special trailer to transport containers to handover points, so that cargo bikes are able to pick the containers up to do the last-mile delivery [126]. In 2017, DHL Express piloted the City Hub concept in Frankfurt, Germany, and Utrecht, Netherlands [137]. The concept of City Hub is similar to the idea from Velove, the vehicles combined with a customized trailer carrying up to four containers, then use of DHL Cubicycles (a cargo-bike able to carry a container) to complete last-mile delivery [137]. In addition, the concept of mobile depot is also a typical integration case. In May of 2013, TNT Express introduced the mobile depot in Brussels [138], which is used to load the goods that will be then driven to a central parking location in the city and be carried out by several electric tricycles as the last-mile delivery [116]. Concurrently, some vehicle manufacturers have also launched new future transport modes to city logistics. For example, in Hannover Messe 2018, Volkswagen (Berlin, Germany) has put forward the concept of Future Urban Freight Mobility as well as a 1:10 model, which is a mobile depot with autonomous driving, equipped with the several delivery robots for carrying goods within urban areas. In summary, the logistics providers and technology enterprises have begun to integrate the various distribution innovations to construct the new distribution concept of urban freight transport, which has an extensive consensus for coping with the environmental externalities. However, the lack of a systematic analysis of the current status on integration of distribution innovations can be observed.

To this end, this paper systematically analyzed the current status of integration on these 11 emerging transport modes through the literature review. As depicted in Table 6, the result has 
demonstrated that many researches have begun to integrate among the several transport modes. Due to some types of innovative transport modes still being in the theoretical research or testing phase, as well as their applied restriction as mentioned before, their integration status is unable to be further analyzed, such as delivery robots and taxis. According to the relevance analysis in Table 6, the electric vehicle and the cargo bike have been extensively used in the operations with the other emerging transport modes. It is noted that these operating modes have applied the standardized box/container (the capacity is approximately $\left.1-2 \mathrm{~m}^{3}\right)[126,128,129,136]$. From the application results of these companies, this delivery model has radically reduced emissions and congestion while increasing the enterprises' competitive ability $[8,10,133,136,138]$. Meanwhile, for the some future integration concepts, they mentioned the feasibility and suitability of the standardized box/container as well. For example, James Kelly and Marinov [62] suggested urban freight distribution using a light rail system based on standardized box/container; Yamato has used a similar concept of a standardized container to transport goods in the urban tram system [8]. Hence, using a standardized container/box is a key element for the integration of these distribution innovations. Indeed, this integrated operational scheme is obviously a special type of intermodal transportation within urban areas. This notwithstanding, the analysis result also indicates that less research has comprehensively considered the inner-urban intermodal transport from the viewpoint of the retail/post industry.

Table 6. Relevance analysis of various technologies.

\begin{tabular}{|c|c|c|c|c|c|c|c|c|c|c|c|}
\hline & $\begin{array}{l}\text { Electric } \\
\text { Vehicles }\end{array}$ & $\begin{array}{l}\text { Modular } \\
\text { E-vehicles }\end{array}$ & $\begin{array}{l}\text { Cargo } \\
\text { Bikes }\end{array}$ & $\begin{array}{l}\text { Delivery } \\
\text { Drones }\end{array}$ & $\begin{array}{l}\text { Public } \\
\text { Transit } \\
\text { System }\end{array}$ & $\begin{array}{l}\text { Robotic } \\
\text { Vehicles }\end{array}$ & Taxi & $\begin{array}{l}\text { Inland } \\
\text { Waterway }\end{array}$ & $\begin{array}{l}\text { Parcel } \\
\text { Lockers }\end{array}$ & $\begin{array}{l}\text { Mobile } \\
\text { Depots }\end{array}$ & $\begin{array}{c}\text { Delivery } \\
\text { Robot }\end{array}$ \\
\hline $\begin{array}{l}\text { Electric } \\
\text { vehicles }\end{array}$ & / & & $\sqrt{ }$ & $\sqrt{ }$ & $\sqrt{ }$ & & & $\sqrt{ }$ & $\sqrt{ }$ & $\sqrt{ }$ & \\
\hline $\begin{array}{l}\text { Modular } \\
\text { E-vehicles }\end{array}$ & & / & & & & & & & & & \\
\hline $\begin{array}{l}\text { Cargo } \\
\text { bike }\end{array}$ & $\sqrt{ }$ & & / & & $\sqrt{ }$ & & & $\sqrt{ }$ & $\sqrt{ }$ & $\sqrt{ }$ & \\
\hline $\begin{array}{l}\text { Delivery } \\
\text { drones }\end{array}$ & $\sqrt{ }$ & & & I & & $\sqrt{ }$ & & & $\sqrt{ }$ & & \\
\hline $\begin{array}{l}\text { Public } \\
\text { transit } \\
\text { system }\end{array}$ & $\sqrt{ }$ & & $\sqrt{ }$ & & / & & & & & $\sqrt{ }$ & \\
\hline $\begin{array}{l}\text { Robotic } \\
\text { vehicles }\end{array}$ & & & & $\sqrt{ }$ & & I & & & & & \\
\hline Taxi & & & & & & & 1 & & & & \\
\hline $\begin{array}{c}\text { Inland } \\
\text { waterway }\end{array}$ & $\sqrt{ }$ & & $\sqrt{ }$ & & & & & I & & & \\
\hline $\begin{array}{l}\text { Parcel } \\
\text { lockers }\end{array}$ & $\sqrt{ }$ & & $\sqrt{ }$ & $\sqrt{ }$ & & & & & / & & \\
\hline $\begin{array}{l}\text { Mobile } \\
\text { depots }\end{array}$ & $\sqrt{ }$ & & $\sqrt{ }$ & & $\sqrt{ }$ & & & & & / & \\
\hline $\begin{array}{l}\text { Delivery } \\
\text { robot }\end{array}$ & & & & & & & & & & & I \\
\hline
\end{tabular}

In addition, Table 6 also indicates that the integration of urban freight innovations is an efficient solution to promote a sustainable and livable city. Much research and some enterprises have proposed one or two transport modes operated together as a system. For instance, mobile depots have been discussed with the use of cargo bikes to deliver goods [115,116,127], and the use of delivery drones was discussed in the application of parcel lockers [125]. Hence, urban intermodal transport is the future research and application direction, aimed at applying the various emerging technologies in the urban freight system. However, a considerable body of research has paid little attention to the integrated application of these emerging transport modes, in particular to their combined operation as a system. Concurrently, comprehensively considering the application restrictions of these transport 
modes in the urban areas is necessary. Therefore, this paper has proposed sustainable inner-urban intermodal transport for future freight within urban areas.

Intermodal transportation refers to using multiple modes of transportation in an intermodal container or vehicle, from origin to destination, without handling of goods themselves or changing the type of their unitization [139-141]. Urban intermodal transportation (UIT) involves the integrated use of a high carrying capacity mode (rail or barge) to transport the containers between the port and intermodal terminals, after which trucks are used to transport these goods to the consumer location/warehouses [142,143]. Indeed, an important definition of the intermodality is the ability to consider many transport modes (e.g., rail, trucks) that operate together as a system [144]. According to the literature review and analysis of the implementation status, there are eleven emerging transport modes that will be applied in the future urban freight transport. Hence, we proposed the concept of sustainable inner-urban intermodal transport (SIUIT) for the future urban freight transport (as depicted in Figure 8). The concept of SIUIT is defined as the combined use of various emerging transport modes (e.g., tram, bus, cargo bike) to transport goods by small modular containers from a city's logistics center to consumers. As mentioned previously, inner-urban intermodal transport has received more attention in recent years, in particular with the postal and retail industries. Using various innovative transport modes in different logistics processes, it is able to provide an individual logistics service while reducing the negative impacts and costs, thereby improving the competitiveness of the enterprise, as well as achieving a livable and sustainable city.

The integration of the various distribution innovations is a challenge for urban freight transport. The existing issues include the special infrastructure construction (e.g., urban freight tram station [62]), structure changes of the urban freight network (e.g., the urban freight network of triple helix model [121]), software platform establishment (e.g., usage of delivery robot and drone), as well as the formulation of urban freight policy and laws, etc. In addition, urban development is also radically impacted by freight transport due to the city and freight having maintained a set of core relations [2]. However, considerable research has paid less attention to links between city development and the integration of urban freight distribution based on the previous analysis. To this end, further research of SIUIT needs to consider comprehensively the future trends of urban development. For example, urban population growth causes increasing freight flow; urbanization and suburbanization lead to the growth of delivery range; as well as a sustainable and livable city desired by urban residents. Besides these, according to relevance analysis of distribution innovations in Table 6, we have found that integrating all 11 distribution innovations into one system is unnecessary. Not only the purpose of these integration modes is to radically relieve the environmental externalities created by city logistics, selected parts of innovations to construct a suitable scheme of SIUIT are necessary. Hence, the selection and integration between the distinct innovations produce the different operational scheme of SIUIT. Which type of SIUIT is suitable for different a city environment needs to be further investigated. The purpose of this paper is to propose the concept of SIUIT, as well as the direction of further research.

As a consequence, SIUIT is the future trend of urban logistics, whose operational measures and existing risks should be integrated into the planning phase of the urban freight system. The advantages of this concept are its use of standardized small boxes/containers to transport goods in the various segments of urban freight transport while applying these emerging transport modes to alleviate environmental externalities. In future research, we need to consider the suitability of SIUIT according to a cost-benefit analysis. In addition, the application limitations and existing risks need further analysis and assessment. Currently, it is noted that the combined operation of these emerging modes as a system has demonstrated effectiveness, particularly in the aspects of congestion and emissions. However, these results were solely obtained for the integrated operation between one or two emerging transport modes. Therefore, future research needs to consider comprehensively the combined operation of all emerging technologies, namely sustainable inner-urban intermodal transport. 


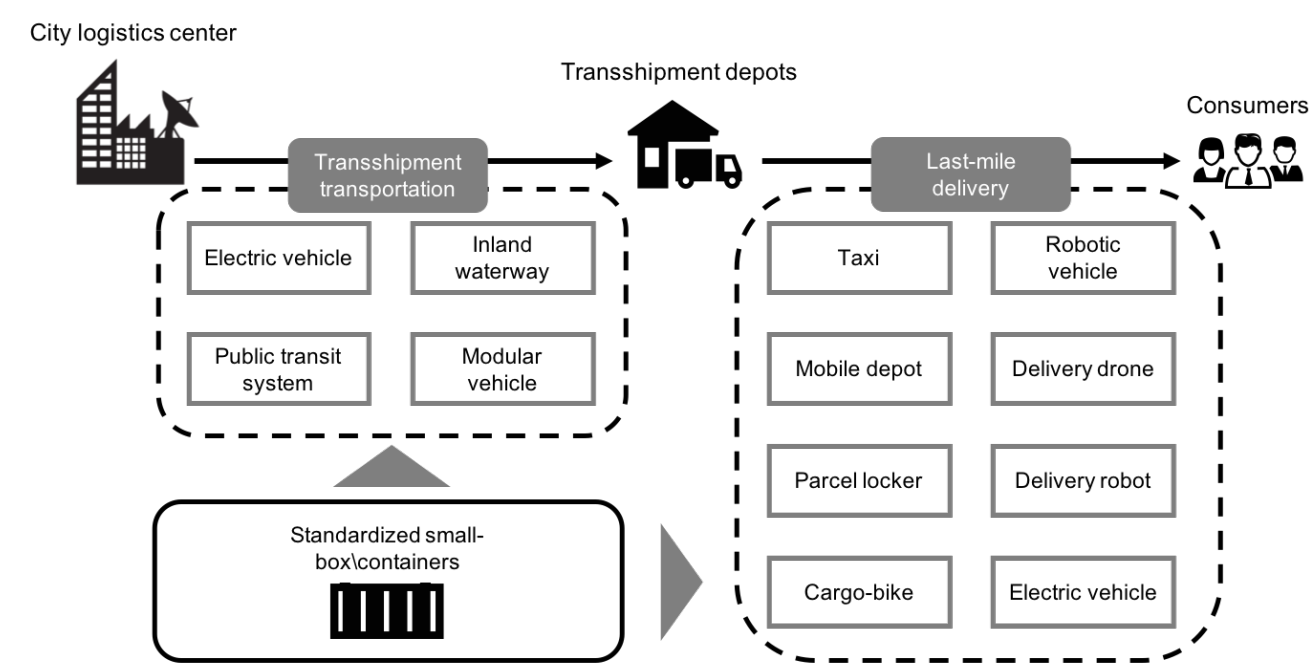

Figure 8. The concept of sustainable inner-urban intermodal transportation.

\section{Conclusions}

This paper has reviewed the articles regarding the emerging transport modes that were published in the past six years (2013-2018). Following the literature reviews, we defined the concept of distribution innovations, which consist of eleven emerging transport modes. The results indicated that the research of various distribution innovations is highly fragmented. A considerable body of research has paid scant attention to the application status of these innovations. To this end, we used the approach of GE multifactorial analysis to analyze the implementation status from the perspectives of academia and companies. There were six types of emerging transport modes in the asymmetric application phase. According to the GE matrix, we demonstrated the future direction of these six types of modes from the academia and company perspectives separately. Concurrently, the literature review indicated that the research on suitability assessments of distribution innovations is extremely scarce. Hence, this paper has reviewed the related enterprises' official reports and case studies in articles, thereby assessing the suitability and limitations of these emerging transport modes. Finally, we have proposed the concept of SIUIT and a further research direction for future urban freight transport.

As the aim of this paper is proposing the concept of SIUIT based on the status analysis of the distribution innovations, as well as their suitability assessment, this paper did not further analyze the applied restriction of SIUIT in future urban development and their potential issues, as well as the selection and combination scheme of distribution innovations in SIUIT. For this reason, further research can be as follows: (1) comprehensively considering the future urban development to design a feasible scheme of SIUIT from the viewpoint of management and economic; (2) further analysis and design of the network structure of urban freight to which SIUIT is applicable and suiting the future urban development; (3) from the perspective of the decision makers and stakeholders, we will attempt to further analyze the selection and combination scheme of these distribution innovations.

Author Contributions: In this paper, Z.H. developed the research ideas, analyzed the results, as well as completed the original writing of the paper. The research methodology was designed by H.-D.H. and Z.H. together. Furthermore, H.-D.H. reviewed the paper.

Funding: This research received no external funding.

Acknowledgments: The publication of this paper was supported by Staats- und Universitaetsbibliothek Bremen (SuUB), Germany.

Conflicts of Interest: The authors declare no conflict of interest. 


\section{References}

1. UNHabitat. World Cities Report 2016. Urbanization and Development: Emerging Futures; UNHabitat: New York, NY, USA, 2016.

2. Rodrigue, J.P.; Comtois, C.; Slack, B. The Geography of Transport Systems; Routledge: London, UK, 2016.

3. ALICE/ERTRAC Urban mobility WG. Urban Freight Research Roadmap; Technical Report November 2014; ERTRAC: Brussels, Belgium, 2014.

4. Anderson, S.; Allen, J.; Browne, M. Urban logistics-How can it meet policy makers' sustainability objectives? J. Transp. Geogr. 2005, 13, 71-81. [CrossRef]

5. Wittlöv, A. Urban freight transport: Challenges and opportunities. In Urban Freight for Livable Cities: How to Deal with Collaboration and Trade-Offs; Tryckeri AB Orion: Täby, Sweden, 2012; pp. 12-23.

6. World Economic Forum (WEF). Supply Chain Decarbonization and the Role of Logistics and Transport in Reducing Supply Chain Carbon Emissions; WEF: Geneva, Switzerland, 2009; p. 41.

7. U.S. Department of Transportation. Bureau of Transportation and Statistics: Commodity Flow Survey; U.S. Department of Transportation: Washington, DC, USA, 2009.

8. Kikuta, J.; Ito, T.; Tomiyama, I.; Yamamoto, S.; Yamada, T. New Subway-Integrated City Logistics Szystem. Procedia Soc. Behav. Sci. 2012, 39, 476-489. [CrossRef]

9. Taniguchi, E.; Thompson, R.G.; Yamada, T. New Opportunities and Challenges for City Logistics. Transp. Res. Procedia 2016, 12, 5-13. [CrossRef]

10. Maes, J.; Sys, C.; Vanelslander, T. City logistics by water: Good practices and scope for expansion. Oper. Res./Comput. Sci. Interfaces Ser. 2015, 58, 413-437. [CrossRef]

11. Starship. The Self-Driving Delivery Robot. Available online: https://www.starship.xyz/business/ (accessed on 3 December 2018).

12. Mercedes-Benz. Intelligently Network Delivery Vehicle of the Future. Available online: https://www. mercedes-benz.com/en/mercedes-benz/vehicles/transporter/vision-van/ (accessed on 3 December 2018).

13. Japan for Sustainability. Yamato Starts Using Streetcars for Low-Carbon Parcel Transport. Available online: https://www.japanfs.org/en/news/archives/news_id031255.html (accessed on 15 May 2018).

14. Inventiva. Starship is using self-driving robots to deliver packages on demand. Available online: https: / / www.inventiva.co.in/2018/10/31/starship-is-using-self-driving-robots-to-deliver-packages-ondemand/ (accessed on 23 November 2018).

15. Tiffany Hsu. Mercedes-Benz to Show Drone Mothership Vision Van at CES. Available online: https: / / www.trucks.com/2017/01/04/mercedes-benz-drone-vision-van-ces/ (accessed on 7 March 2018).

16. Cepolina, E.M. The packages clustering optimisation in the logistics of the last mile freight distribution. Int. J. Simul. Process Model. 2016, 11, 468. [CrossRef]

17. Lewandowski, K. Reliability of the delivery in the last 100 meters. In Safety and Reliability: Methodology and Applications_-Proceedings of the European Safety and Reliability Conference, ESREL 2014; CRC Press/Balkema: Boca Raton, FL, USA, 2015; pp. 2377-2386. [CrossRef]

18. Moutaoukil, A.; Neubert, G.; Derrouiche, R. Urban freight distribution: The impact of delivery time on sustainability. IFAC-PapersOnLine 2015, 28, 2368-2373. [CrossRef]

19. Wang, X. The Trend of Urban Freight Regulatory Path under the Cloud. In Proceedings of the Fifth International Conference on Transportation Engineering (ICTE 2015), Dailan, China, 26-27 September 2015; pp. 2102-2108. [CrossRef]

20. Bates, O.; Knowles, B.; Friday, A. Are People the Key to Enabling Collaborative Smart Logistics? In Proceedings of the 2017 CHI Conference Extended Abstracts on Human Factors in Computing Systems (CHI EA 2017), Denver, CO, USA, 6-11 May 2017; Volume 2050, pp. 1494-1499. [CrossRef]

21. Dablanc, L.; Morganti, E.; Arvidsson, N.; Woxenius, J.; Browne, M.; Saidi, N. The rise of on-demand 'Instant Deliveries' in European cities. Supply Chain Forum 2017, 18, 203-217. [CrossRef]

22. Cardenas, I.D.; Dewulf, W.; Vanelslander, T.; Smet, C.; Beckers, J. The e-commerce parcel delivery market and the implications of home B2C deliveries vs pick-up points. Int. J. Transp. Econ. 2017, 44, 235-256. [CrossRef]

23. Allen, J.; Piecyk, M.; Piotrowska, M.; McLeod, F.; Cherrett, T.; Ghali, K.; Nguyen, T.; Bektas, T.; Bates, O.; Friday, A.; et al. Understanding the impact of e-commerce on last-mile light goods vehicle activity in urban areas: The case of London. Transp. Res. Part D Transp. Environ. 2018, 61, 325-338. [CrossRef] 
24. Pan, S.; Giannikas, V.; Han, Y.; Grover-Silva, E.; Qiao, B. Using customer-related data to enhance e-grocery home delivery. Ind. Manag. Data Syst. 2017, 117, 1917-1933. [CrossRef]

25. Köster, F.; Ulmer, M.W.; Mattfeld, D.C. Cooperative traffic control management for city logistic routing. Transp. Res. Procedia 2015, 10, 673-682. [CrossRef]

26. Rizet, C.; Cruz, C.; Vromant, M. The Constraints of Vehicle Range and Congestion for the Use of Electric Vehicles for Urban Freight in France. Transp. Res. Procedia 2016, 12, 500-507. [CrossRef]

27. Lebeau, P.; Macharis, C.; Mierlo, J.V. The choice of battery electric vehicles for urban logistics: A conjoint based choice analysis. In Proceedings of the EVS28 International Electric Vehicle Symposium and Exhibition, Goyang, Korea, 3-6 May 2015; pp. 1-7.

28. Giordano, A.; Fischbeck, P.; Matthews, H.S. Environmental and economic comparison of diesel and battery electric delivery vans to inform city logistics fleet replacement strategies. Transp. Res. Part D. Transp. Environ. 2018, 64, 216-229. [CrossRef]

29. Teoh, T.; Kunze, O.; Teo, C.C.; Wong, Y.D. Decarbonisation of urban freight transport using electric vehicles and opportunity charging. Sustainability 2018, 10, 3258. [CrossRef]

30. Koh, M.; Czimmermann, P.; Michal, V. Location-scheduling optimization problem to design private charging infrastructure for electric vehicles. In Proceedings of the International Conference on Operations Research and Enterprise Systems, Porto, Portugal, 23-25 February 2017; Springer: Cham, Switzerland, 2017; Volume 695. [CrossRef]

31. Cagliano, A.C.; Carlin, A.; Mangano, G.; Rafele, C. Analyzing the diffusion of eco-friendly vans for urban freight distribution. Int. J. Logist. Manag. 2017, 28, 1218-1242. [CrossRef]

32. Franceschetti, A.; Honhon, D.; Laporte, G.; Woensel, T.V.; Fransoo, J.C. Strategic fleet planning for city logistics. Transp. Res. Part B Methodol. 2017, 95, 19-40. [CrossRef]

33. Taefi, T.T.; Stütz, S.; Fink, A. Assessing the cost-optimal mileage of medium-duty electric vehicles with a numeric simulation approach. Transp. Res. Part D Transp. Environ. 2017, 56, 271-285. [CrossRef]

34. Wa̧tróbski, J.; Małecki, K.; Kijewska, K.; Iwan, S.; Karczmarczyk, A.; Thompson, R. Multi-Criteria Analysis of Electric Vans for City Logistics. Sustainability 2017, 9, 1453. [CrossRef]

35. Cossu, P. Clean Last Mile Transport and Logistics Management for Smart and Efficient Local Governments in Europe. Transp. Res. Procedia 2016, 14, 1523-1532. [CrossRef]

36. Taefi, T.T. Viability of electric vehicles in combined day and night delivery: A total cost of ownership example in Germany. Eur. J. Transp. Infrastruct. Res. 2016, 16, 512-553.

37. Yang, J.; Guo, J.; Ma, S. Low-carbon city logistics distribution network design with resource deployment. J. Clean. Prod. 2016, 119, 223-228. [CrossRef]

38. Ahani, P.; Arantes, A.; Melo, S. A portfolio approach for optimal fleet replacement toward sustainable urban freight transportation. Transp. Res. Part D Transp. Environ. 2016, 48, 357-368. [CrossRef]

39. Lebeau, P.; Macharis, C.; Van Mierlo, J. Exploring the choice of battery electric vehicles in city logistics: A conjoint-based choice analysis. Transp. Res. Part E Logist. Transp. Rev. 2016, 91, 245-258. [CrossRef]

40. Schau, V.; Apel, S.; Gebhardt, K.; Kretzschmar, J.; Stolcis, C.; Mauch, M.; Buchholz, J. Intelligent Infrastructure for Last-mile and Short-distance Freight Transportation with Electric Vehicles in the Domain of Smart City Logistic. In Proceedings of the International Conference on Vehicle Technology and Intelligent Transport Systems, Rome, Italy, 23-24 April 2016; pp. 149-159. [CrossRef]

41. Quak, H.; Nesterova, N.; Van Rooijen, T.; Dong, Y. Zero Emission City Logistics: Current Practices in Freight Electromobility and Feasibility in the Near Future. Transp. Res. Procedia 2016, 14, 1506-1515. [CrossRef]

42. Taefi, T.T.; Kreutzfeldt, J.; Fink, A. Yielding a treasure: A transition management approach to electric urban freight vehicles in Germany. In Proceedings of the EVS 2016-29th International Electric Vehicle Symposium, Montreal, QC, Canada, 19-22 June 2016.

43. Schau, V.; Apel, S.; Gebhard, K.; Mauch, M.; Rossak, W. ICT-systems for electric vehicles within simulated and community based environments. In Communications in Computer and Information Science; Springer: Cham, Switzerland, 2016; Volume 648, pp. 217-222. [CrossRef]

44. Liakos, P.; Angelidis, I.; Delis, A. Cooperative routing and scheduling of an electric vehicle fleet managing dynamic customer requests. In Lecture Notes in Computer Science (Including Subseries Lecture Notes in Artificial Intelligence and Lecture Notes in Bioinformatics); Springer: Cham, Switzerland, 2016; Volume 10033 LNCS, pp. 118-135. [CrossRef] 
45. Lebeau, P.; Macharis, C.; Mierlo, J.V.; Lebeau, K. Electrifying light commercial vehicles for city logistics? A total cost of ownership analysis. Eur. J. Transp. Infrastruct. Res. 2015, 15, 551-569.

46. Schau, V.; Rossak, W.; Hempel, H.; Spathe, S. Smart City Logistik Erfurt (SCL): ICT-support for managing fully electric vehicles in the domain of inner city freight traffic: A Look at an ongoing federal project in the City of Erfurt, Germany. In Proceedings of the 5th International Conference on Industrial Engineering and Operations Management (IEOM 2015), Dubai, UAE, 3-5 March 2015. [CrossRef]

47. Lebeau, P.; De Cauwer, C.; Van Mierlo, J.; Macharis, C.; Verbeke, W.; Coosemans, T. Conventional, Hybrid, or Electric Vehicles: Which Technology for an Urban Distribution Centre? Sci. World J. 2015, 2015, 302867. [CrossRef] [PubMed]

48. Taefi, T.T.; Kreutzfeldt, J.; Held, T.; Fink, A. Strategies to Increase the Profitability of Electric Vehicles in Urban Freight Transport. In E-Mobility in Europe: Trends and Good Practice; Springer: Cham, Switzerland, 2015; pp. 367-388. [CrossRef]

49. Roumboutsos, A.; Kapros, S.; Vanelslander, T. Green city logistics: Systems of Innovation to assess the potential of E-vehicles. Res. Transp. Bus. Manag. 2014, 11, 43-52. [CrossRef]

50. Lebeau, P.; Macharis, C.; van Mierlo, J.; Maes, G. Implementing electric vehicles in urban distribution: A discrete event simulation. World Electr. Veh. J. 2013, 6, 38-47. [CrossRef]

51. Melo, S.; Baptista, P.; Costa, Á. The cost and effectiveness of sustainable city logistics policies using small electric vehicles. Transp. Sustain. 2014, 6, 295-314. [CrossRef]

52. Lebeau, P.; Macharis, C.; Van Mierlo, J.; Lebeau, K. Electric vehicles for logistics: A total cost of ownership analysis. In Proceedings of the BIVEC-GIBET Transport Research Days 2013, Barcelona, Spain, 17-20 November 2013; pp. 307-318. [CrossRef]

53. Van Duin, J.H.R.; Tavasszy, L.A.; Quak, H.J. Towards E (Lectric)-Urban Freight: First Promising Steps in the Electric Vehicle Revolution; EUT Edizioni Università di Trieste: Tirieste, Italy, 2014; pp. 1-19.

54. Pelletier, S.; Jabali, O.; Laporte, G. Charge scheduling for electric freight vehicles. Transp. Res. Part B Methodol. 2018, 115, 246-269. [CrossRef]

55. Morganti, E.; Browne, M. Technical and operational obstacles to the adoption of electric vans in France and the UK: An operator perspective. Transp. Policy 2018, 63, 90-97. [CrossRef]

56. Mirhedayatian, S.M.; Yan, S. A framework to evaluate policy options for supporting electric vehicles in urban freight transport. Transp. Res. Part D Transp. Environ. 2018, 58, 22-38. [CrossRef]

57. Muñoz-Villamizar, A.; Quintero-Araújo, C.L.; Montoya-Torres, J.R.; Faulin, J. Short-and mid-term evaluation of the use of electric vehicles in urban freight transport collaborative networks: A case study. Int. J. Logist. Res. Appl. 2018, 1-24. [CrossRef]

58. Lebeau, P.; Macharis, C.; Van Mierlo, J.; Janjevic, M. Improving policy support in city logistics: The contributions of a multi-actor multi-criteria analysis. Case Stud. Transp. Policy 2018, 6, 554-563. [CrossRef]

59. Rezgui, D.; Aggoune-Mtalaa, W.; Bouziri, H. Towards the electrification of urban freight delivery using modular vehicles. In Proceedings of the 10th IEEE International Conference oN Service Operations and Logistics, and Informatics (SOLI 2015) - In Conjunction with ICT4ALL 2015, Hammamet, Tunisia, 15-17 November 2015; pp. 154-159. [CrossRef]

60. Andaloro, L.; Napoli, G.; Sergi, F.; Micari, S.; Agnello, G.; Antonucci, V. Development of a new concept electric vehicle for last-mile transportations. World Electr. Veh. J. 2015, 7, 342-348. [CrossRef]

61. Khadraoui, D.; Aggoune-Mtalaa, W.; Ait Ouahmed, A.; Habbas, Z. Solving new urban freight distribution problems involving modular electric vehicles. IET Intell. Transp. Syst. 2015, 9, 654-661. [CrossRef]

62. Kelly, J.; Marinov, M. Innovative Interior Designs for Urban Freight Distribution Using Light Rail Systems. Urban Rail Transit 2017, 3, 238-254. [CrossRef]

63. De Langhe, K. The importance of external costs for assessing the potential of trams and trains for urban freight distribution. Res. Transp. Bus. Manag. 2017, 24, 114-122. [CrossRef]

64. Gonzalez-Feliu, J. Viability and potential demand capitation of urban freight tramway systemss via demand-supply modelling and cost benefit analysis. In Proceedings of the 6th International Conference on Information Systems, Logistics and Supply Chain (ILS 2016), Bordeaux, France, 1-4 June 2016; pp. 1-9.

65. Strale, M. The Cargo Tram: Current Status and Perspectives, the Example of Brussels; Sustainable Logistics. Emerald Group Publishing Limited: Bingley, UK, 2014; pp. 245-263. 
66. Wang, L.S.; Deng, Q.M. A Portable Subway Logistics System for the Transportation of Small and Medium-Size Cargo. Adv. Mater. Res. 2013, 734-737, 1604-1608. [CrossRef]

67. Regué, R.; Bristow, A.L. Appraising freight tram schemes: A case study of Barcelona. Eur. J. Transp. Infrastruct. Res. 2013, 13, 56-78.

68. Liu, S.; Xu, J.; Shi, X.; Li, G.; Liu, D. Sustainable distribution organization based on the supply-demand coordination in large Chinese cities. Sustainability 2018, 10, 3042. [CrossRef]

69. Behiri, W.; Belmokhtar-Berraf, S.; Chu, C. Urban freight transport using passenger rail network: Scientific issues and quantitative analysis. Transp. Res. Part E Logist. Transp. Rev. 2018, 115, 227-245. [CrossRef]

70. Ozturk, O.; Patrick, J. An optimization model for freight transport using urban rail transit. Eur. J. Oper. Res. 2018, 267, 1110-1121. [CrossRef]

71. Gonzalez-Feliu, J. A joint freight catchment and cost benefit analysis to assess rail urban logistics scenarios. In Lecture Notes in Business Information Processing; Springer: Cham, Switzerland, 2018. [CrossRef]

72. Zhao, L.; Li, H.; Li, M.; Sun, Y.; Hu, Q.; Mao, S.; Li, J.; Xue, J. Location selection of intra-city distribution hubs in the metro-integrated logistics system. Tunn. Undergr. Space Technol. 2018, 80, 246-256. [CrossRef]

73. Serafini, S.; Nigro, M.; Gatta, V.; Marcucci, E. Sustainable crowdshipping using public transport: A case study evaluation in Rome. Transp. Res. Procedia 2018, 30, 101-110. [CrossRef]

74. Dong, J.; Hu, W.; Yan, S.; Ren, R.; Zhao, X. Network Planning Method for Capacitated Metro-Based Underground Logistics System. Adv. Civ. Eng. 2018, 2018, 6958086. [CrossRef]

75. Pimentel, C.; Alvelos, F. Integrated urban freight logistics combining passenger and freight flows-Mathematical model proposal. Transp. Res. Procedia 2018, 30, 80-89. [CrossRef]

76. Ewedairo, K.; Chhetri, P.; Jie, F. Estimating transportation network impedance to last-mile delivery a case study of maribyrnong city in melbourne. Int. J. Logist. Manag. 2018, 29, 110-130. [CrossRef]

77. Labanauskas, G. Development of inland waterway transport for Kaunas City logistics. In Transport Means_Proceedings of the International Conference. Kaunas University of Technology; Kaunas University of Technology: Kaunas, Lithuania, 2016; pp. 1131-1134.

78. Janjevic, M.; Ndiaye, A.B. Inland waterways transport for city logistics: A review of experiences and the role of local public authorities. WIT Trans. Built Environ. 2014, 138, 279-292. [CrossRef]

79. Seidlová, A.; Šourek, D.; Ledvinová, M. Distribution models using waterway transport for city logistics. In Transport Means_-Proceedings of the International Conference; Kaunas University of Technology: Kaunas, Lithuania, 2017; pp. 220-225.

80. Chen, C.; Pan, S. Using the crowd of taxis to last-mile delivery in e-commerce: A methodological research. In Studies in Computational Intelligence; Springer: Berlin, Germany, 2016; Volume 640, pp. 61-70. [CrossRef]

81. Eidhammer, O.; Andersen, J.; Johansen, B.G. Private Public Collaboration on Logistics in Norwegian Cities. Transp Res. Procedia 2016, 16, 81-88. [CrossRef]

82. Li, B.; Krushinsky, D.; Reijers, H.A.; Van Woensel, T. The Share-A-Ride Problem: People and parcels sharing taxis. Eur. J. Oper. Res. 2014, 238, 31-40. [CrossRef]

83. Zhang, R.; Wang, L. A study on price evaluation and management of urban freight taxi in Shanghai. In CICTP 2017: Transportation Reform and Change_Equity, Inclusiveness, Sharing, and Innovation-Proceedings of the 17th COTA International Conference of Transportation Professionals; American Society of Civil Engineers: Reston, Virginia, USA, 2018; pp. 1472-1480.

84. Gao, C.; Yang, J.; Xu, J.; Chu, P.; Zhang, L. The design and analysis of the matching system for the urban freight taxis. In CICTP 2017: Transportation Reform and Change-Equity, Inclusiveness, Sharing, and Innovation-Proceedings of the 17th COTA International Conference of Transportation Professionals; American Society of Civil Engineers: Reston, VA, USA, 2018; pp. 1447-1452.

85. Rudolph, C.; Gruber, J. Cargo cycles in commercial transport: Potentials, constraints, and recommendations. Res. Transp. Bus. Manag. 2017, 24, 26-36. [CrossRef]

86. Melo, S.; Baptista, P. Evaluating the impacts of using cargo cycles on urban logistics: Integrating traffic, environmental and operational boundaries. Eur. Transp. Res. Rev. 2017, 9, 30. [CrossRef]

87. Anderluh, A.; Hemmelmayr, V.C.; Nolz, P.C. Synchronizing Vans and Cargo Bikes in a City Distribution Network; Springer: Berlin/Heidelberg, Germany, 2017; Volume 25, pp. 345-376. [CrossRef]

88. Koning, M.; Conway, A. The good impacts of biking for goods: Lessons from Paris city. Case Stud. Transp. Policy 2016, 4, 259-268. [CrossRef] 
89. Schier, M.; Offermann, B.; Weigl, J.D.; Maag, T.; Mayer, B.; Rudolph, C.; Gruber, J. Innovative two wheeler technologies for future mobility concepts. In Proceedings of the 2016 11th International Conference on Ecological Vehicles and Renewable Energies (EVER 2016), Monte Carlo, Monaco, 6-8 April 2016. [CrossRef]

90. Choubassi, C.; Seedah, D.P.K.; Jiang, N.; Walton, C.M. Economic Analysis of Cargo Cycles for Urban Mail Delivery. Transp. Res. Rec. J. Transp. Res. Board 2016, 2547, 102-110. [CrossRef]

91. Gruber, J.; Kihm, A. Reject or Embrace? Messengers and Electric Cargo Bikes. Transp. Res. Procedia 2016, 12, 900-910. [CrossRef]

92. Gruber, J.; Rudolph, C.; Kolarova, V. Factors determining the introduction of cargo bikes in urban commercial transport [Einflussfaktoren bei der Einführung des Lastenrads im urbanen Wirtschaftsverkehr]. Z. Wirtsch. 2015, 59, 115-129.

93. Schliwa, G.; Armitage, R.; Aziz, S.; Evans, J.; Rhoades, J. Sustainable city logistics-Making cargo cycles viable for urban freight transport. Res. Transp. Bus. Manag. 2015, 15, 50-57. [CrossRef]

94. Gruber, J.; Kihm, A.; Lenz, B. A new vehicle for urban freight? An ex-ante evaluation of electric cargo bikes in courier services. Res. Transp. Bus. Manag. 2014, 11, 53-62. [CrossRef]

95. Lenz, B.; Riehle, E. Bikes for Urban Freight? Transp. Res. Rec. J. Transp. Res. Board 2013, $2379,39-45$. [CrossRef]

96. Sárdi, D.L.; Bóna, K. Macroscopic simulation model of a multi-stage, dynamic cargo bike-based logistics system in the supply of shopping malls in Budapest. In Proceedings of the 2018 Smart Cities Symposium Prague (SCSP 2018), Prague, Czech Republic, 24-25 May 2018; pp. 1-7. [CrossRef]

97. Arnold, F.; Cardenas, I.; Sörensen, K.; Dewulf, W. Simulation of B2C e-commerce distribution in Antwerp using cargo bikes and delivery points. Eur. Transp. Res. Rev. 2018, 10. [CrossRef]

98. Lopez, O.N. Urban vehicle access regulations. Oper. Res./Comput.Sci. Interfaces Ser. 2018, 63, 139-163. [CrossRef]

99. Vleugel, J.M.; Bal, F. More space and improved living conditions in cities with autonomous vehicles. Int. J. Des. Nat. Ecodyn. 2017, 12, 505-515. [CrossRef]

100. Haas, I.; Friedrich, B. Developing a micro-simulation tool for autonomous connected vehicle platoons used in city logistics. Transp. Res. Procedia 2017, 27, 1203-1210. [CrossRef]

101. Mitrea, O.; Kyamakya, K. (How) will autonomous driving influence the future shape of city logistics? J. Appl. Eng. Sci. 2017, 15, 45-52. [CrossRef]

102. Yu, J.J.; Lam, A.Y. Autonomous Vehicle Logistic System: Joint Routing and Charging Strategy. IEEE Trans. Intell. Transp. Syst. 2017, 19, 2175-2187. [CrossRef]

103. Molfino, R.; Zoppi, M.; Dinale, A.; Muscolo, G.G. A robotic vehicle for freight delivery in urban areas. In Proceedings of the 16th International Conference on Harbor, Maritime and Multimodal Logistics Modelling and Simulation (HMS 2014), Bordeaux, France, 10-12 September 2014; pp. 154-159.

104. Dinale, A.; Molfino, R.; Huang, P.; Zoppi, M. A new robotized vehicle for urban freight transport. In Proceedings of the International Conference on Harbour, Maritime and Multimodal Logistics Modelling and Simulation, Athens, Greece, 25-27 September 2013; Volume 1, pp. 32-37.

105. Muscolo, G.G.; Moregola, G.; Molfino, R. A preliminary study to optimise safety conditions on a freight urban robotic vehicle. Int. J. Veh. Saf. 2018, 10. [CrossRef]

106. Scherr, Y.O.; Neumann-Saavedra, B.A.; Hewitt, M.; Mattfeld, D.C. Service Network Design for Same Day Delivery with Mixed Autonomous Fleets. Transp. Res. Procedia 2018, 30, 23-32. [CrossRef]

107. Beirigo, B.A.; Schulte, F.; Negenborn, R.R. Integrating People and Freight Transportation Using Shared Autonomous Vehicles with Compartments. IFAC-PapersOnLine 2018, 51, 392-397. [CrossRef]

108. Kunze, O. Replicators, Ground Drones and Crowd Logistics A Vision of Urban Logistics in the Year 2030. Transp. Res. Procedia 2016, 19, 286-299. [CrossRef]

109. Mckinnon, A.C. The possible impact of 3D printing and drones on last-mile logistics: An exploratory study. Built Environ. 2016, 42, 617-629. [CrossRef]

110. Mbiadou Saleu, R.G.; Deroussi, L.; Feillet, D.; Grangeon, N.; Quilliot, A. An iterative two-step heuristic for the parallel drone scheduling traveling salesman problem. Networks 2018, 72, 459-474. [CrossRef]

111. Boysen, N.; Briskorn, D.; Fedtke, S.; Schwerdfeger, S. Drone delivery from trucks: Drone scheduling for given truck routes. Networks 2018, 72, 506-527. [CrossRef]

112. Lemke, J.; Iwan, S.; Korczak, J. Usability of the Parcel Lockers from the Customer Perspective-The Research in Polish Cities. Transp. Res. Procedia 2016, 16, 272-287. [CrossRef] 
113. Iwan, S.; Kijewska, K.; Lemke, J. Analysis of Parcel Lockers' Efficiency as the Last Mile Delivery Solution-The Results of the Research in Poland. Transp. Res. Procedia 2016, 12, 644-655. [CrossRef]

114. Deutsch, Y.; Golany, B. A parcel locker network as a solution to the logistics last-mile problem. Int. J. Prod. Res. 2018, 56, 251-261. [CrossRef]

115. Arvidsson, N.; Pazirandeh, A. An ex ante evaluation of mobile depots in cities: A sustainability perspective. Int. J. Sustain. Transp. 2017, 11, 623-632. [CrossRef]

116. Verlinde, S.; Macharis, C.; Milan, L.; Kin, B. Does a Mobile Depot Make Urban Deliveries Faster, More Sustainable and More Economically Viable: Results of a Pilot Test in Brussels. Transp. Res. Procedia 2014, 4, 361-373. [CrossRef]

117. Marujo, L.G.; Goes, G.V.; D'Agosto, M.A.; Ferreira, A.F.; Winkenbach, M.; Bandeira, R.A. Assessing the sustainability of mobile depots: The case of urban freight distribution in Rio de Janeiro. Transp. Res. Part D Transp. Environ. 2018, 62, 256-267. [CrossRef]

118. Wikipedia. GE Multifactorial Analysis. Available online: https://en.wikipedia.org/wiki/GE_multifactorial_ analysis (accessed on 11 February 2019).

119. Geels, F.W. The dynamics of transitions in socio-technical systems: A multi-level analysis of the transition pathway from horse-drawn carriages to automobiles (1860-1930). Technol. Anal. Strateg. Manag. 2005, 17, 445-476. [CrossRef]

120. Kersten, W.; Seiter, M.; Von See, B.; Hackius, N.; Maurer, T. Trends and Strategies in Logistics and Supply Chain Management; DVV Media Group GmbH: Hamburg, Germany, 2017; p. 71.

121. Verlinde, S.; Macharis, C. Innovation in Urban Freight Transport: The Triple Helix Model. Transp. Res. Procedia 2016, 14, 1250-1259. [CrossRef]

122. Workhorse Group. HorseFly UAV Delivery System. Available online: http://workhorse.com/aerospace (accessed on 7 June 2019).

123. Amazon Prime Air. Amazon Prime Air. Available online: https://www.amazon.com/Amazon-Prime-Air/ $\mathrm{b}$ ?ie=UTF8\&node=8037720011 (accessed on 3 April 2018).

124. Zoe Kleinman. Ocado Trials Driverless Delivery Van in London. Available online: http:/ /www.bbc.com/ news/technology-40421100 (accessed on 3 December 2018).

125. Deutsche Post DHL Group. DHL Parcelcopter. Available online: https://www.dpdhl.com/en/mediarelations / specials / dhl-parcelcopter.html (accessed on 3 December 2018).

126. Velove Cororpation. The Armadillo. Available online: https://www.velove.se/electric-cargo-bike (accessed on 11 February 2019).

127. Ducret, R. Parcel deliveries and urban logistics: Changes and challenges in the courier express and parcel sector in Europe-The French case. Res. Transp. Bus. Manag. 2014, 11, 15-22. [CrossRef]

128. Behiri, W.; Ozturk, O.; Belmokhtar-Berraf, S. Urban Freight by Rail: A MILP Modeling for Optimizing the Transport of Goods. In Proceedings of the 6th International Conference on Information Systems, Logistics and Supply Chain, Bordeaux, France, 1-4 June 2016; pp. 2-9.

129. Masson, R.; Trentini, A.; Lehuédé, F.; Malhéné, N.; Péton, O.; Tlahig, H. Optimization of a city logistics transportation system with mixed passengers and goods. EURO J. Transp. Logist. 2017, 6, 81-109. [CrossRef]

130. Auto-Date. Technical Specifications and Fuel Economy of Automobiles. Available online: https://www. auto-data.net/en/ (accessed on 5 November 2018).

131. Mercedes-Benz. Taxi und Mietwagen. Available online: https://www.mercedes-benz.de/passengercars / buy/fleet-and-business/fb/taxi.html (accessed on 3 December 2019).

132. Agatz, N.; Bouman, P.; Schmidt, M. Optimization approaches for the traveling salesman problem with drone. Transp. Sci. 2018, 52, 965-981. [CrossRef]

133. Deutsche Post DHL Group. Rapid Response from the Air: Medicines Successfully Delivered Using a Parcel Drone in East Africa. Available online: https://www.dpdhl.com/en/media-relations/press-releases/2018/ rapid-response-from-the-air-medicines-successfully-delivered-using-a-parcel-drone-in-east-africa.html (accessed on 3 December 2018).

134. KEBA. Reliable Self-Service Parcel Lockers. Available online: https:/ /www.keba.com/en/logistics-solutions / products/lockers/lockers (accessed on 11 December 2018).

135. STRAIGHTSOL. TNT Express in Brussels-City Logistics Mobile Depot. Available online: http://www. straightsol.eu/demonstration_B.htm (accessed on 3 December 2018). 
136. DHL Express Company. City Logistics DHL Express. Available online: https://www.dhlexpress.nl/sites/ default/files/City\%20Logistics\%20DHL\%20Express.pdf (accessed on 3 December 2018).

137. Deutsche Post DHL Group. DHL Cubicycles City Hub Frankfurt 02. Available online: https://www.dpdhl. $\mathrm{com} / \mathrm{en} /$ media-relations/media-center/tv-footage/dhl-cubicycles-city-hub-frankfurt-02.html (accessed on 11 February 2019).

138. Express, T. TNT Express Introduces Mobile Depot in Brussels. Available online: https://www.tnt.com/ corporate/en/data/press/2013/05/tnt-express-introduces-mobile-depot-in-Brussels.html (accessed on 11 February 2019).

139. Secreteriat, U. Implementation of Multimodal Transport Rules; UNCTAD Secretariat: Geneva, Switzerland, 2001.

140. Munim, Z.H.; Haralambides, H. Competition and cooperation for intermodal container transhipment: A network optimization approach. Res. Transp. Bus. Manag. 2018, 26, 87-99. [CrossRef]

141. Wikipedia. Intermodal Freight Transportation. Available online: https://en.wikipedia.org/wiki/ Intermodal_freight_transport (accessed on 3 December 2018).

142. Meyrick and Associates. National Intermodal Terminal Study; Technical Report; Meyrick Consulting Group Pty Ltd: Wollongong, Australia, 2006.

143. Teye, C.; H Bell, M.G.; J Bliemer, M.C. Optimal location of open access urban container terminals under elastic cargo demand. In Proceedings of the 38th Australasian Transport Research Forum, Melbourne, Victoria, Australia, 16-18 November 2016; pp. 1-14.

144. Cuncev, I. The Management of Intermodality in Urban Transportation. In Proceedings of the CODATU XI: World Congress: Towards More Attractive Urban Transportation, Bucarest, Romanian, 22-24 April 2004.

(C) 2019 by the authors. Licensee MDPI, Basel, Switzerland. This article is an open access article distributed under the terms and conditions of the Creative Commons Attribution (CC BY) license (http:/ / creativecommons.org/licenses/by/4.0/). 